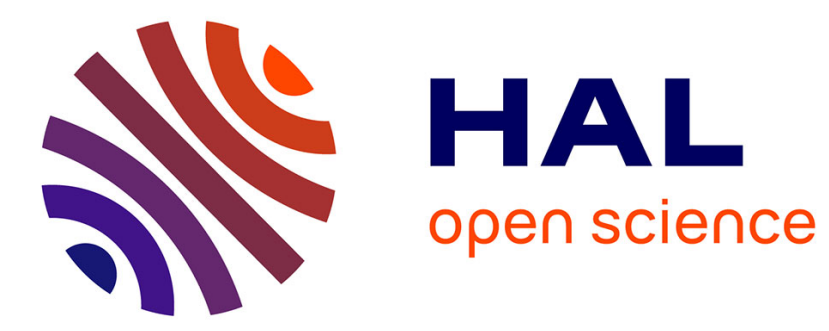

\title{
The measurement of financial intermediation in Japan
}

Gunther Capelle-Blancard, Jézabel Couppey-Soubeyran, Laurent Soulat

\section{To cite this version:}

Gunther Capelle-Blancard, Jézabel Couppey-Soubeyran, Laurent Soulat. The measurement of financial intermediation in Japan. Japan and the World Economy, 2008, 20 (1), pp.40-60. 10.1016/j.japwor.2006.08.005 . halshs-00265547

\section{HAL Id: halshs-00265547 https://shs.hal.science/halshs-00265547}

Submitted on 19 Mar 2008

HAL is a multi-disciplinary open access archive for the deposit and dissemination of scientific research documents, whether they are published or not. The documents may come from teaching and research institutions in France or abroad, or from public or private research centers.
L'archive ouverte pluridisciplinaire HAL, est destinée au dépôt et à la diffusion de documents scientifiques de niveau recherche, publiés ou non, émanant des établissements d'enseignement et de recherche français ou étrangers, des laboratoires publics ou privés. 


\title{
The measurement of financial intermediation in Japan*
}

\author{
Gunther CAPELLE-BLANCARD ${ }^{\#}$ \\ Jézabel COUPPEY-SOUBEYRAN ${ }^{\$}$ \\ Laurent SOULAT ${ }^{\Upsilon}$
}

Revised version: August, 2006

\begin{abstract}
In this paper, we examine the evolution of the Japanese financial structure, in order to challenge the expected incidences of the financial liberalization. We compute financial intermediation ratios for Japan (1979-2004) on a book value basis. According to our results, the intermediation ratio has remained quite stable, at around $85 \%$. This stability is the result of two opposite trends: a decrease in credits and an increase in financial securities owned by financial (mostly, non-banking) institutions. These two trends are partly the consequence of the heavier weight of the Government in domestic external financing, which is traditionally less financed by credits than companies are. Besides, these two trends would not have appeared if we had used intermediation ratios in market value or other traditional indicators (Deposits/GDP, Loans to private sector/GDP, stock market capitalization/GDP, etc.). Our results provide evidence for a very close relationship between intermediate financings and market financings and tend to reject the hypothesis of the Japanese financial system's convergence toward a capital market-based system.
\end{abstract}

JEL Classification: G10, G21, G32, G38.

Keywords: Disintermediation, financial system, intermediaries, capital markets.

\footnotetext{
* The authors thank Michel Boutillier, Hélène Raymond-Feingold, Reinhard H. Schmidt and the referee for helpful comments.

\# EconomiX-Université Paris X Nanterre, CES-Université Paris 1 Panthéon-Sorbonne \& CNRS. Corresponding address: 106-112 Blvd de l'Hôpital 75647 Cedex 13 Paris, France. Email: gunther.capelle-blancard@univ-paris1.fr.

\CES-Université Paris 1 Panthéon-Sorbonne \& CNRS. Email: couppey@univ-paris1.fr.

$\Upsilon$ CES-Université Paris 1 Panthéon-Sorbonne \& CNRS. Email: soulat@univ-paris1.fr.
} 


\section{The measurement of financial intermediation in Japan}

\section{Introduction}

During the 1980s and the beginning of the 1990s, the Japanese banking sector underwent a partial financial liberalization. Manufacturing firms gained in independence vis-à-vis banks more quickly than did savers. Consequently, banks stayed large, but they had to find new opportunities for loans as the banking regulation prevented them from redeploying their activity. Some of the Japanese banks were even reluctant to write off bad loans and enter into forbearance lending (Kobayashi, Saita and Sekine, 2002).

For Hoshi and Kashyap (1999), the asymmetry in the liberalization process played a key role in the banking crisis and needed to be corrected by a deeper deregulation. The Japanese Big Bang initiated in 1996 was aimed at radically transforming the financial system toward a market-based system. Hoshi and Kashyap (1999) expected the Big Bang would lead "more firms to migrate to capital market financing", and would induce "a massive contraction in the size of the Japanese banking sector". Anderson and Makhija (1999) underlined, as a result of this financial liberalization, "a disintermediation evident in Japanese balance sheets". Such an analysis of the financial mutation incidences is not specific to Japan, but is often applied to many other countries (see, for instance, Allen and Santomero, 2001 and Rajan and Zingales, 2003a). Three points are generally considered.

The first one deals with the incidence of financial mutation on the relative importance of financial intermediaries compared to capital markets. A current view is that financial development is prejudicial to banks. Capital markets compete with banks on both sides of the bank's balance sheet. On the assets side, the increase in claims undermines credit. On the liabilities side, the development of collective saving (which occurred relatively late in Japan) increases the cost of resources collected by banks. As a consequence, traditional banking firms should decline and there should be a necessary redeployment towards other activities such as financial engineering, risk management, etc. (Boot and Thakor, 2000). In the specific case of Japan, the decline of traditional banking would also be accompanied by a weakening of the main banking relationships.

The second point relates to the global evolution of financial systems. Nowadays, the majority opinion puts forward the idea of a standardization of financial systems toward a capital marketbased system, in opposition to a bank-based system. Interestingly, the only empirical study specifically dedicated to this phenomenon (Schmidt, Hackethal and Tyrell, 1999) finds neither a global trend toward disintermediation nor a convergence toward capital market-based financial systems in the major European economies (France, Germany or the United Kingdom) at a general level.

The third question concerns the relative merits of bank-based versus capital market-based systems (for a comprehensive discussion on comparative financial systems, see Allen and Gale, 2000 and Levine, 2002). For a long time, the literature seemed to conclude in favor of capital market-based systems, at least for developed countries (Boyd and Smith, 1998). However, several recent studies using cross-country comparisons challenge this idea: although global financial development is a significant determinant of economic growth, there is no support for either the bank-based or market-based view (see Levine, 2005).

One major problem with this traditional approach is that financing structure is always a challenge to quantify (see, for a discussion, Beck, Demirguc-Kunt and Levine, 2001). Consider, for instance, the Japanese case. While Japan is still referred to as an archetype of a bank-based system, Tokyo is one of the leading financial centers in the world; in 2003, Tokyo was ranked first in market capitalization of newly listed domestic shares. Moreover, the Japanese corporate 
bond market is small, but the Japanese Government Bond (JGB) market is the largest in the world. At first sight, one can interpret this as evidence of the convergence of the Japanese financial system toward a capital market-based system. But it seems more interesting to see it as evidence of a close connection between banks and capital markets in the financial system.

Beyond the empirical problem, a more fundamental issue challenges the ground of the traditional approach. The latter considers markets and intermediaries as two substitutable and opposite modalities. But one should not ignore the important interactions between markets and intermediaries: the services provided by each may overlap, and it is very likely that there is crossfertilization between markets and intermediaries. In accordance with Levine (2005), we suggest that the debate should not focus on bank-based versus market-based systems. By nature, the traditional approach cannot cover the whole variety of financial systems. Moreover, this dichotomous vision of financial systems is gradually being replaced by theoretical analyses that underline the complementary quality of financial services. For instance, Bodie and Merton (1995, 2004) argue in favor of a functional approach instead of an institutional one; in this case, banks and capital markets are not opposed, but assume largely identical functions (financing, portfolio management, risk management, liquidity insurance), although in different ways. Moreover, numerous studies challenge the convergence hypothesis by highlighting the role of historical or institutional characteristics such as the legal system, the political context, the cultural and religious legacies, the geographical endowments or the social capital that may shape national financial systems (see, again, Levine 2005). In any case, these conflicting analyses highlight the need for better empirical measures of financing structure.

The aim of this paper is to empirically assess the financial structure in Japan in order to challenge the expected incidences of the financial liberalization. There is little empirical evidence concerning the evolution of the Japanese financial structure and our paper attempts to fill this gap. Traditional measures of financial structure ${ }^{1}$ focus more on the level of financial activity, give a narrow vision of financial intermediation and do not capture its changing nature, nor do they correct for changes in security prices. In this paper, we compute financial intermediation ratios which do not suffer from these drawbacks. In our breakdown of external financing, we do not consider only direct and indirect financing, but we also break down the total financial intermediation ratio into the sum of the credit intermediation ratio and the market intermediation ratio. This finer breakdown allows us to appreciate the modalities and the changing nature of the financial intermediation. Moreover, as flows are too erratic for long-term studies, we use stock series. But stock series are not fully suitable since they are usually expressed in market value, which amplifies financial cycles. Therefore, we correct market value to obtain book value. That is particularly significant in the case of Japan, whose stock exchange market was affected these last decades by episodes of very strong volatility and bull and bear markets.

Our study offers new stylized facts concerning the Japanese financial system: the rise of the capital markets, which started at the beginning of the 1980's, did not involve a disintermediation and, symmetrically, the decline in stock market prices, at the beginning of the 1990s and at the beginning of the 2000s, did not support a re-intermediation in Japan. The financial intermediation ratio remained stable overall between 1979 and 2004. This stability of the financial intermediation ratio is the result of two opposite trends: a decrease in the share of credits in the domestic nonfinancial sectors' external financing (i.e. the credit intermediation ratio) and an increase in the share of investments in claims carried out by banks and other financial intermediaries (i.e. the market intermediation ratio). The first trend results from the decrease in credits requested by corporations and from the reduced share of corporate fund raisings in domestic external financing relative to government, which is traditionnaly less financed by credits. Similarly, the second trend results from the increase in financial institutions' investments

\footnotetext{
1 See, for instance, Edvey and Hidving (1995), Allen and Santomero (2001) or Rajan and Zingales (2003).
} 
in securities issued by the domestic nonfinancial sectors and from the growing share of government in domestic external financing. In other words, the global evolution of intermediation ratios is explained both by the change in the relative weight of governement and corporations in domestic external financing and by significant changes in the financial behavior of domestic nonfinancial agents. The nature of financial intermediairies' participation in the financing of the Japanese economy, therefore, has changed: the increase in claims investments has compensated for the relative fall in credits. However, our results suggest that this evolution in the supply of financing was not due to a proactive behavior of financial intermediairies, but rather mostly reflects the increase in the government need for financing.

The paper is structured as follows. Section 2 presents the data and defines the intermediation scope. Section 3 provides results. Section 4 concludes.

\section{Methodology}

\subsection{Data}

Financial national accounts of Japan (Flow of Funds Accounts) are downloaded from the Bank of Japan website. We use the SNA 93 database recently retropolated to 1979. ${ }^{2}$ The Bank of Japan also provides documents concerning the Japanese channels of fund-raising. These files give outstandings of shares and other equities on a book value basis and outstandings of securities other than shares on a face value basis. Moreover, it allows us to focus on domestic financing to domestic sectors.

\subsection{Intermediation ratios}

A financial intermediation ratio measures the share of intermediate financings in the total of the external financings granted to the domestic nonfinancial sector (DNF). The denominator of the ratio (total of the external financings) is obtained by adding loans and claims issued by the DNF. As we consider only intersectorial external financings, we exclude trade credits. The numerator of the ratio (intermediate financings) has two components:

- the first one we call credit intermediation, it is the total of loans granted by domestic private and public financial institutions (FI);

- the second one we call market intermediation, it is the sum of claims issued by DNF and submitted by all domestic FI. Because only aggregate accounts are available, to identify the stocks of claims held by FI over each sector (NFC, GOV and Overseas) we assume that the fraction of a given category of claims, issued by DNF and purchased by a given category of FI, is equal to the fraction of the same category of claims held by the particular FI, whatever the issuer. If, for instance, insurance companies and pension funds hold $\alpha \%$ of the total stock of bonds, the hypothesis is made that they hold in the same manner $\alpha \%$ of the stock of bonds issued by NFC, $\alpha \%$ of those issued by GOV and $\alpha \%$ of those issued by Overseas.

The sum of credit intermediation and market intermediation forms what we call total intermediation. Three intermediation ratios are computed: the credit intermediation ratio (or strict ratio), the market intermediation ratio, and the ratio of total intermediation (or large ratio as the sum of the two

\footnotetext{
2 In a first draft, before the retropolation of the SNA 93 database, we used two databases: SNA 68 for 1970-1999 (quarterly data) and SNA 93 for 1990-2003 (annual data until 1998, and quarterly data since). Results were qualitavely the same and are avalaible upon request.
} 
preceding ones). Each ratio can be expressed for the DNF sector, or for the two main institutional nonfinancial sectors: private and public nonfinancial corporations (NFC), and general government (GOV). The market intermediation ratio can also be broken down by type of FI active in Japan, to measure the distribution of market share between "banks" and "non-bank FI".

\subsection{Market value versus book value}

Generally, market value data (such as market capitalization, for example) are not appropriate to evaluate the level of financings. Such data integrate particularly significant price effects which completely hide the evolution of the financings itself (volume effect). ${ }^{3}$ This was plainly visible in Japan at the end of the 1980s and the 1990s (cf. Figure 1).

\section{Figure 1. Outstanding of shares and other equities issued by private Japanese nonfinancial corporations}

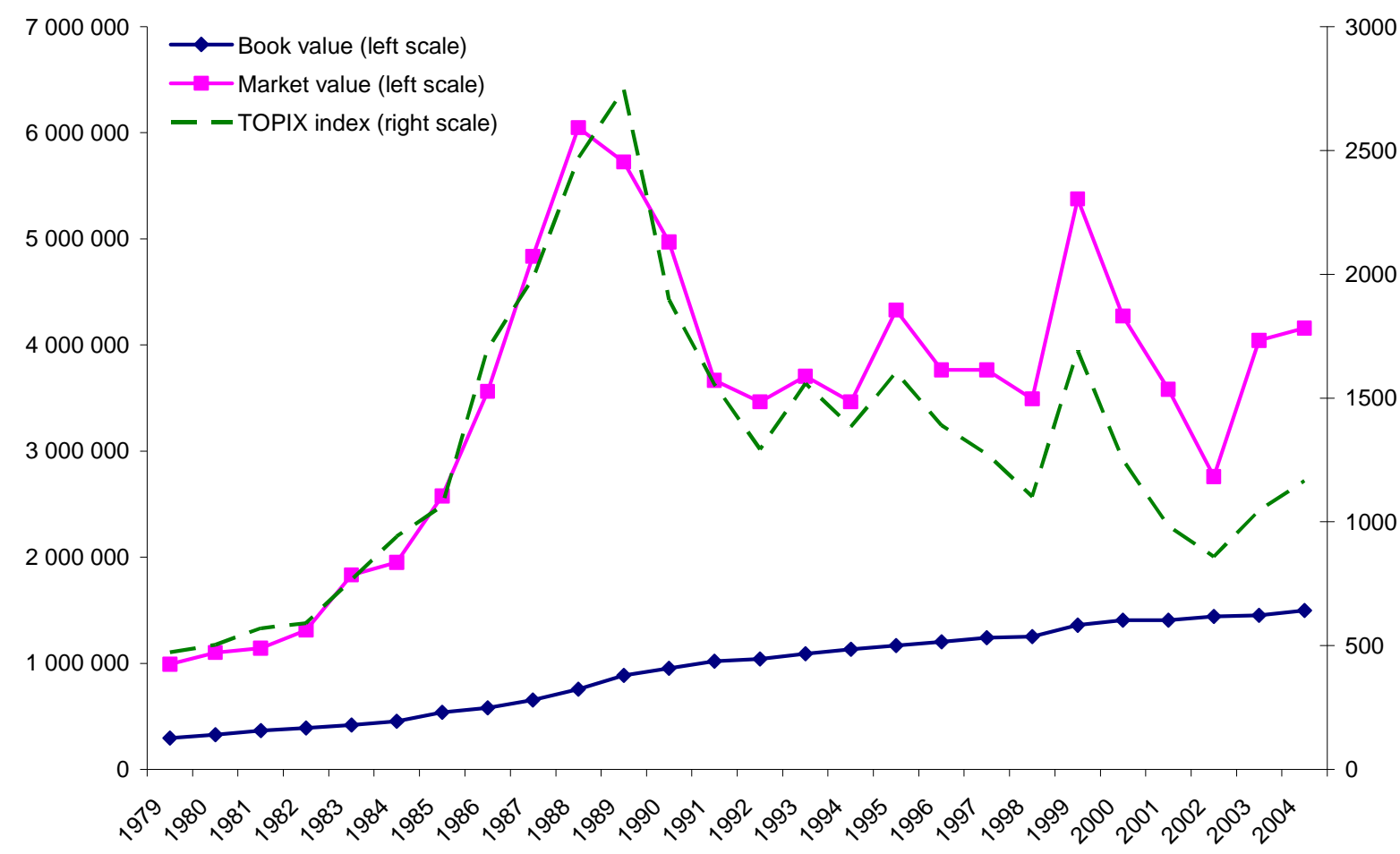

Notes: Outstanding (100 million yen) of shares and other equities issued by private nonfinancial corporations on a market value and a book value basis (source: Flow of Funds Account, SNA 93 - Bank of Japan) on the left scale and Topix Index (source: Datastream) on the right scale.

Stock price effects can lead to significant bias:

- A rise in securities prices significantly weighs down the stock of claims without necessarily increasing external financings. It mechanically lowers the intermediation ratio. Accordingly, the progression of stock market capitalization is often perceived, wrongly, as the sign of a rise

\footnotetext{
3 Rajan and Zingales (2003b) also recognized that equity market capitalization "captures the amount of equity listed, not the amount of equity raised. Thus, the presence of few companies that have greatly appreciated in value can give the impression of a big equity market even when the amount of funds raised in the market is tiny. On the positive side, however, this measure is less cyclical than the previous one, and thus is better for making comparisons across countries and across time periods."
} 
in direct financing and a fall in intermediation.

- The incidence is symmetrical in the case of decreasing securities prices. Indeed, on the other side, when stock market capitalization declines, the denominator of the ratio declines too. But depreciation effects should not be assimilated to a rebound of intermediate financings.

In short, increases in stock market prices lead to the overestimation of the relative importance of market financings and to the underestimation of intermediate financings. In both cases, one would err in not distinguishing between the two distinct tendencies that cause variation in stock market capitalization: on the one hand, an increase or decrease in the issuance of new shares (volume effect) and, on the other hand, price appreciation or depreciation of the existing shares (price effect).

When the intermediation ratio is computed with market values, it is impossible to distinguish between the "price effect" and the "volume effect". Therefore, in this study, intermediation ratios are calculated on a book value basis (see section 2.1). ${ }^{4}$

\section{Results}

Detailed results are presented in Tables A1 to A4 in the Appendix.

\subsection{Credit intermediation and market intermediation}

Between 1979 and 2004, external financing (excluding trade credits) granted to the Japanese domestic non-financial sector were multiplied by four (see Figure 2). This increase was mostly favourable to securities other than shares issues. This segment in the external financing increased from $25 \%$ to $42 \%$, whereas the proportion of shares and other equities grew from $7 \%$ to only $9 \%$. At the same time, banking credits decreased from $68 \%$ to $49 \%$.

It is necessary, however, to underline the stability of the total intermediation ratio. It contrasts with the reduction of the credit intermediation ratio, which is particularly accentuated at the beginning of the 1990s (see Figure 3). The two components of the total ratio, namely the credit intermediation ratio (banking credits as a fraction of external financings) and the market intermediation ratio (claims investments by the FI as a fraction of external financings) each follow a perfectly symmetrical trend. The more the credit intermediation ratio dropped, at the beginning of the 1990s, the more the market intermediation ratio increased. The rise of the market intermediation ratio translates the increasing share of the banking financial institutions and especially of the non-banking ones in the purchases of claims. The share of FI in stockholding increased at the same time as the share of securities increased in external financing. In 2004 , almost $70 \%(64 \%$ in 1979) of the market financings were actually intermediate financings.

\footnotetext{
4 When national accounts are not avalaible on a book value basis, a method consists in dividing stock market capitalization with a stock price index. The choice of a stock price index (see Rousseau and Wachtel (2000)) poses problems of representativeness and does not allow one to take account of the valuation of non-listed shares. It is then preferable to determine a price index computed with flow and stocks data (see Capelle-Blancard and CouppeySoubeyran, 2003).
} 
Figure 2. External Financing by the Japanese Domestic Nonfinancial Sector

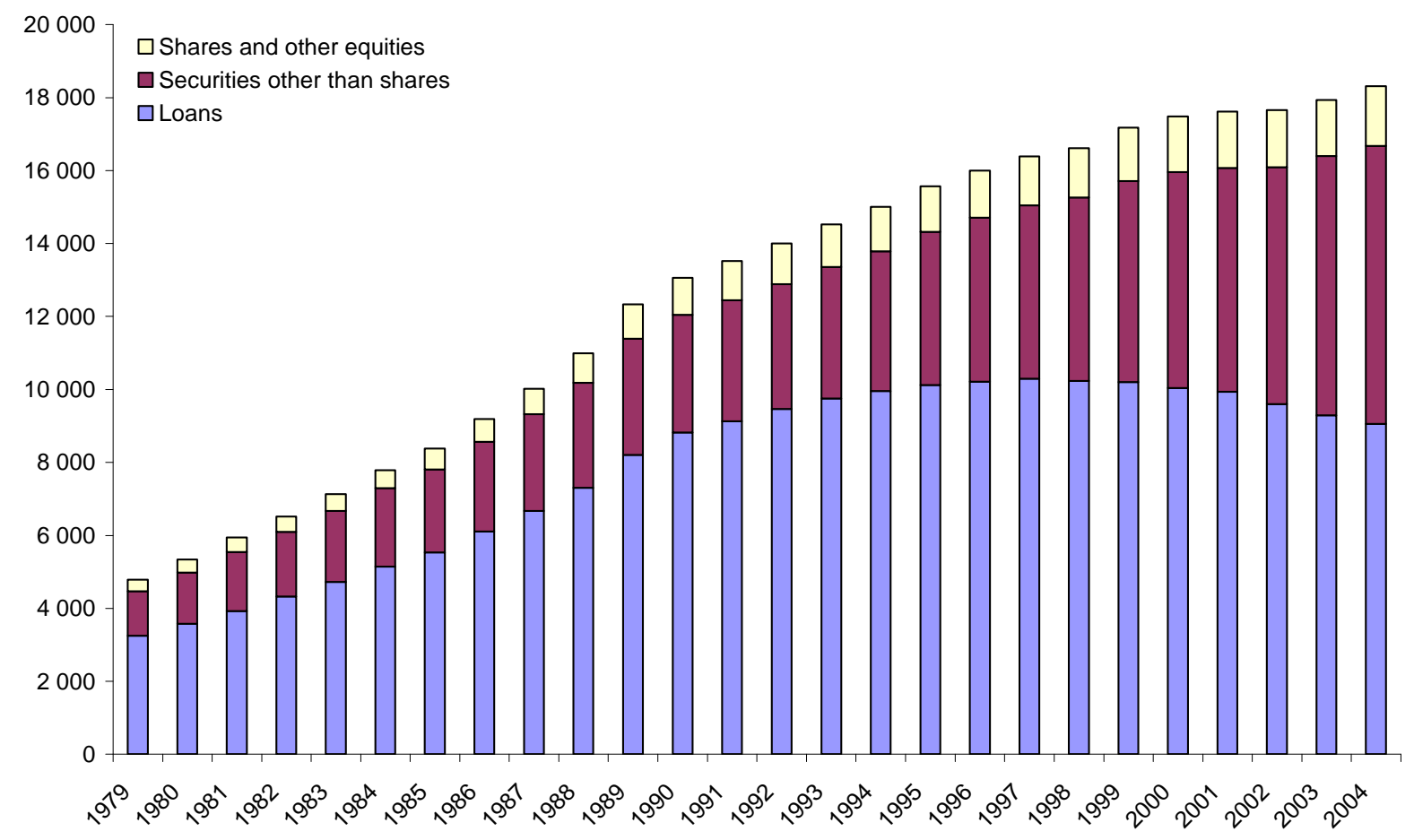

Data: Flow of Funds Account - Bank of Japan. Outstandings on a book value basis.

Figure 3. Japanese intermediation ratios - Domestic Non-financial Sector

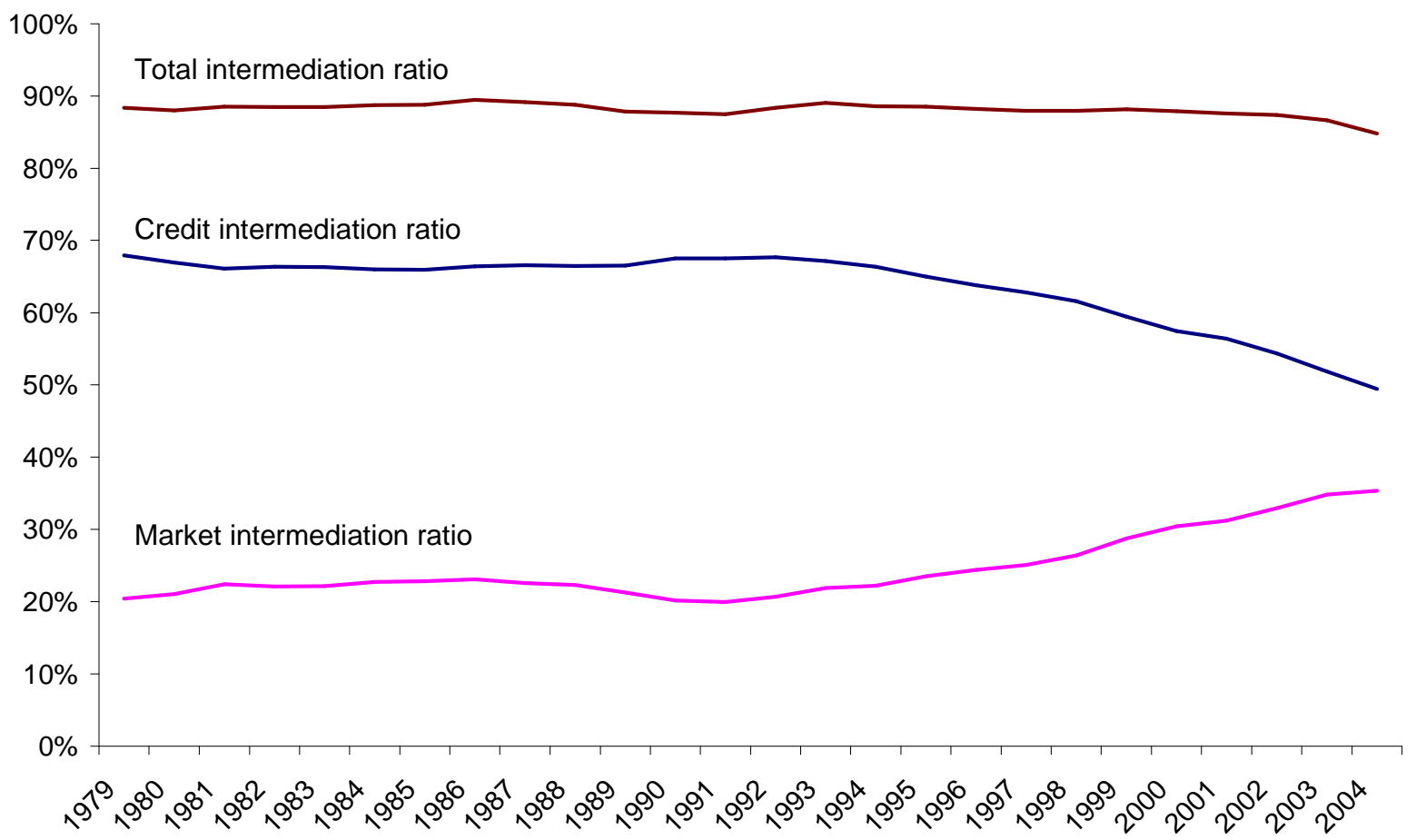

Notes. From top to bottom: 1) Total intermediation ratio $=($ loans + securities held by domestic financial intermediaries) / external financing by the Japanese domestic nonfinancial sector; 2) Credit intermediation ratio = loans / external financing by the Japanese domestic nonfinancial sector; 3) Market intermediation ratio $=$ securities held by financial intermediaries / external financing by the Japanese domestic nonfinancial sector. Data: Flow of Funds Account - Bank of Japan. Outstandings on a book value basis. 
Thus, the degree of intermediation of the financings has remained stable in Japan thanks to the increase in securities investments by the FI, compensating as such for the fall in bank credit. Market development did not reduce the share of intermediate financings in the total external financings, but it did change the nature of the latter. Intermediate financings increasingly became securities investments, therefore market financings. Intermediates financings and market financings appear more and more integrated.

\subsection{The intermediation ratio and stock price effects}

In Europe and the United States, the 1990s were a period of very dynamic stock markets, so much so that a speculative bubble formed and then burst at the beginning of the 2000s. Starting from computations in market values (of stock market capitalization, of credit over external financings, etc.), one would find in this context a disintermediation of financing. The explanation is that a measurement made from market value does not allow one to distinguish between the increase in the supply of stock in the market financings (stock effect) and the valorization effects (price effect). Therefore, by mechanically decreasing the relative share of the intermediate financings, stock exchange valorization masks the true evolution of the latter (a relative stability in the case of Europe, see Capelle-Blancard and Couppey-Soubeyran 2003).

In Japan, the 1980s were a period characterized by a growing asset price bubble and the 1990s a period of a huge financial crisis. Intermediation ratios based on market value during this later period would lead to the fallacious conclusion that intermediation rebounded. But the stock market crisis in Japan was not favorable to intermediation, just as the expansion of capital markets at the same time in Europe did not involve the fall of intermediation. In Europe, the decrease in the intermediation ratios in market value, due to the stock price increase, has been assimilated wrongly to a disintermediation of financing. In Japan, stock price decreases (notably observed during 1990-1992 and 2000-2003) had hidden the contraction in intermediate financing following the banking crisis. Our aim is not only to draw attention to obvious differences in absolute levels between market value and book value or to the more erratic evolution of the market value, but also to emphasize the distorsion of the trends. The contraction of bank credit (see Figure 4) is obscured if we only consider market value during 2000-2003 (the market value ratio remains stable and the book value ratio decreases). The trend is even fully reversed during 1990-1992 (the market value ratio increases and the book value ratio remains stable).

The intermediation ratio of funds raised by NFC and the ratio of funds raised by GOV have a common feature. In both cases, the share of credit in the external financing decreases, while the share of securities issuances (by both NFC and GOV) acquired by the FI increases. The ratios of institutional sectors are then in accordance with the global ratio, but the trends are much less pronounced. 
Figure 4. Credit intermediation ratio on a book and on a market value basis

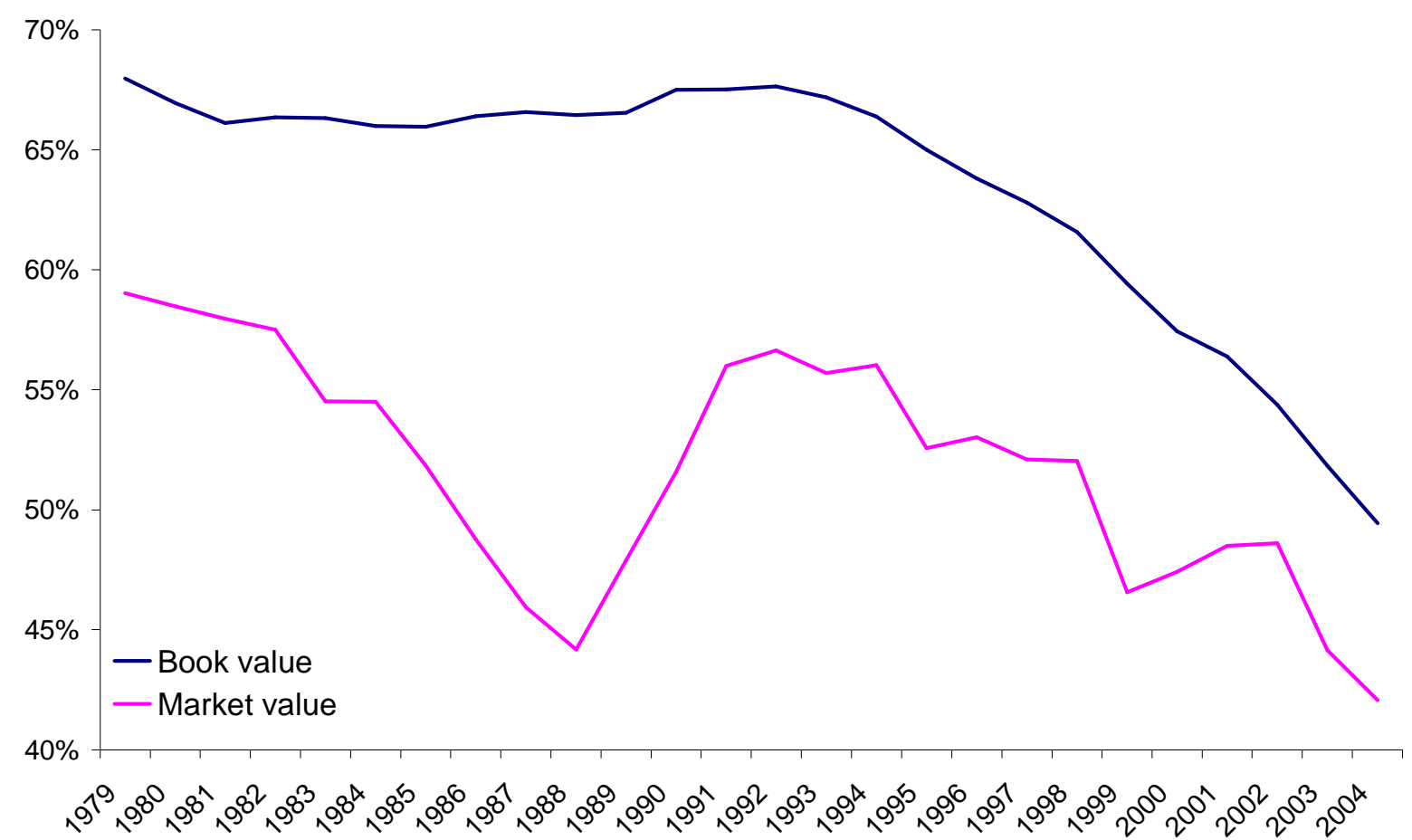

Notes: Credit intermediation ratio $=$ loans / external financing. Outstanding: on market value basis and book value basis. Data: Flow of Funds Account - Bank of Japan.

\subsection{Public versus private financial institutions market shares}

Depository corporations' market shares have decreased gradually throughout the period: $67 \%$ in 1979 against 54\% in 2004 for loans, $42 \%$ in 1979 against 29\% in 2004 for securities other than shares, and 41\% in 1979 against 30\% in 2004 for shares and other equities (see Figure 5). At the opposite, public financial institutions' market shares have increased during the 1990s accordingly to the "ballooning theory" (see for a discussion, Yamori and Nishigaki, 2005). The public financial institutions took advantage of the evolution of the intermediate financing market more than the private non-banking institutions. 


\section{Figure 5. Fund-raising by the Japanese DNF sector from financial institutions}

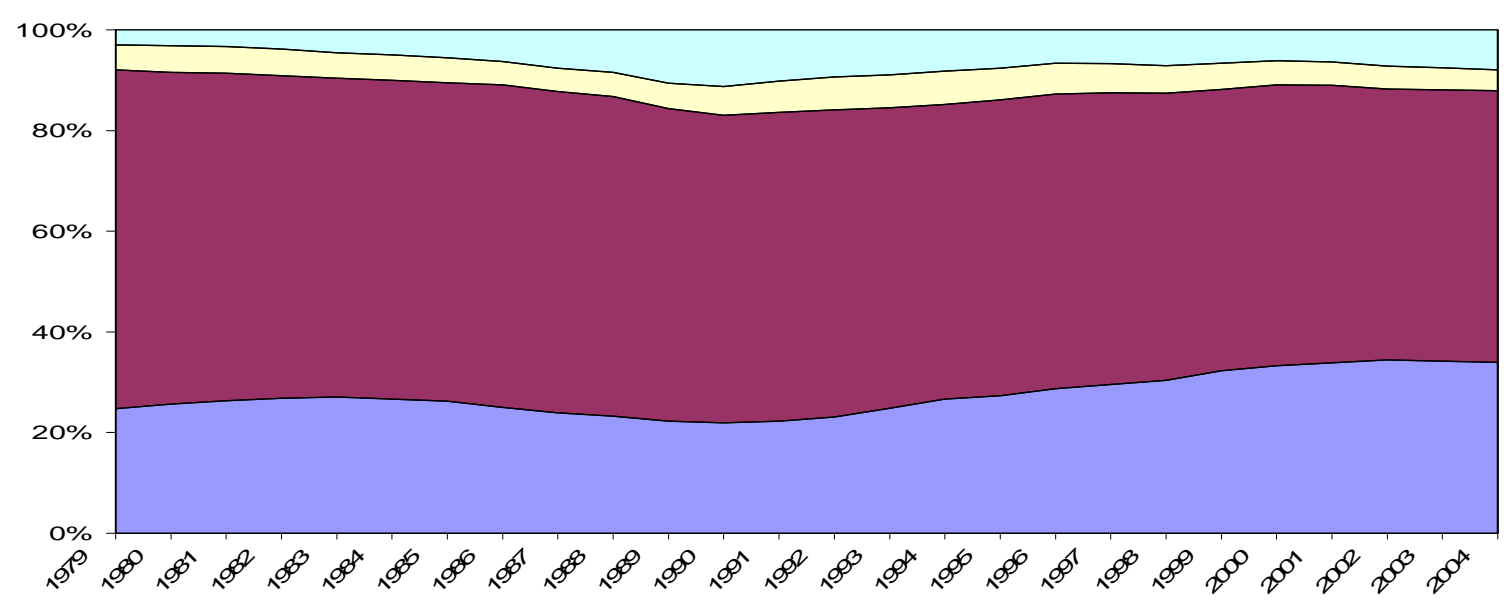

5a. Loans granted by financial intermediaries

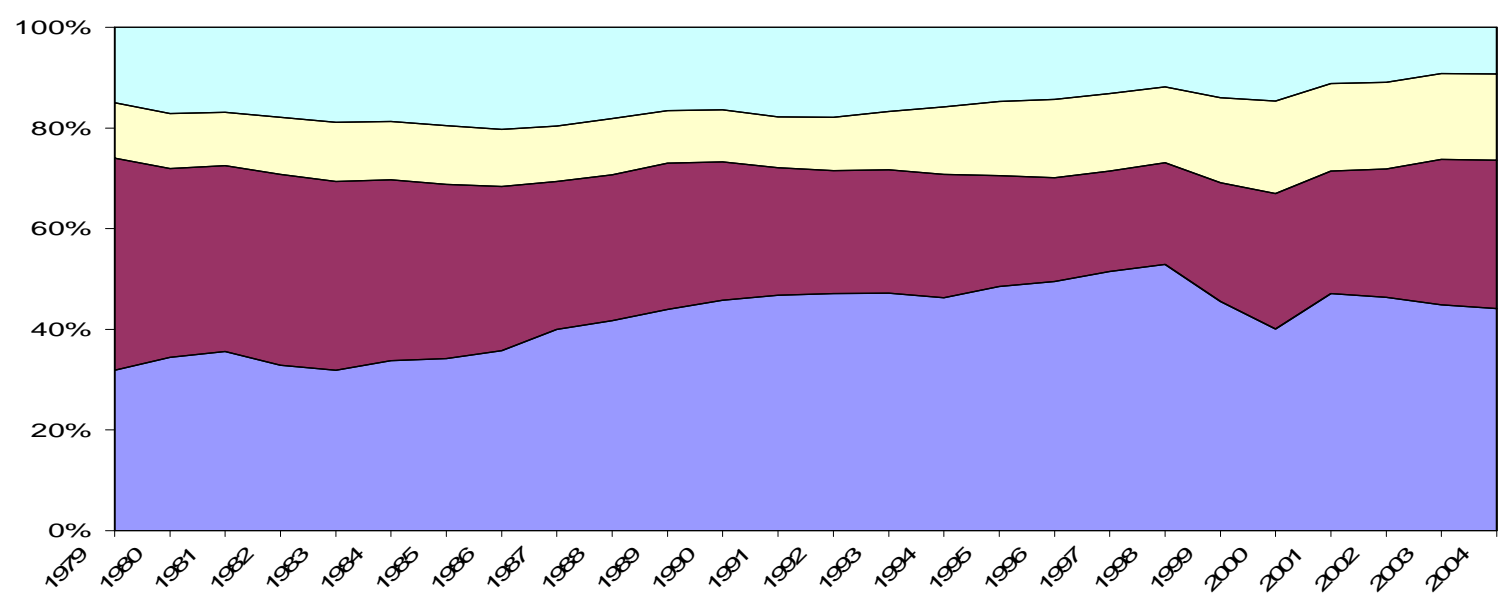

5b. Securities other than shares hold by financial intermediaries

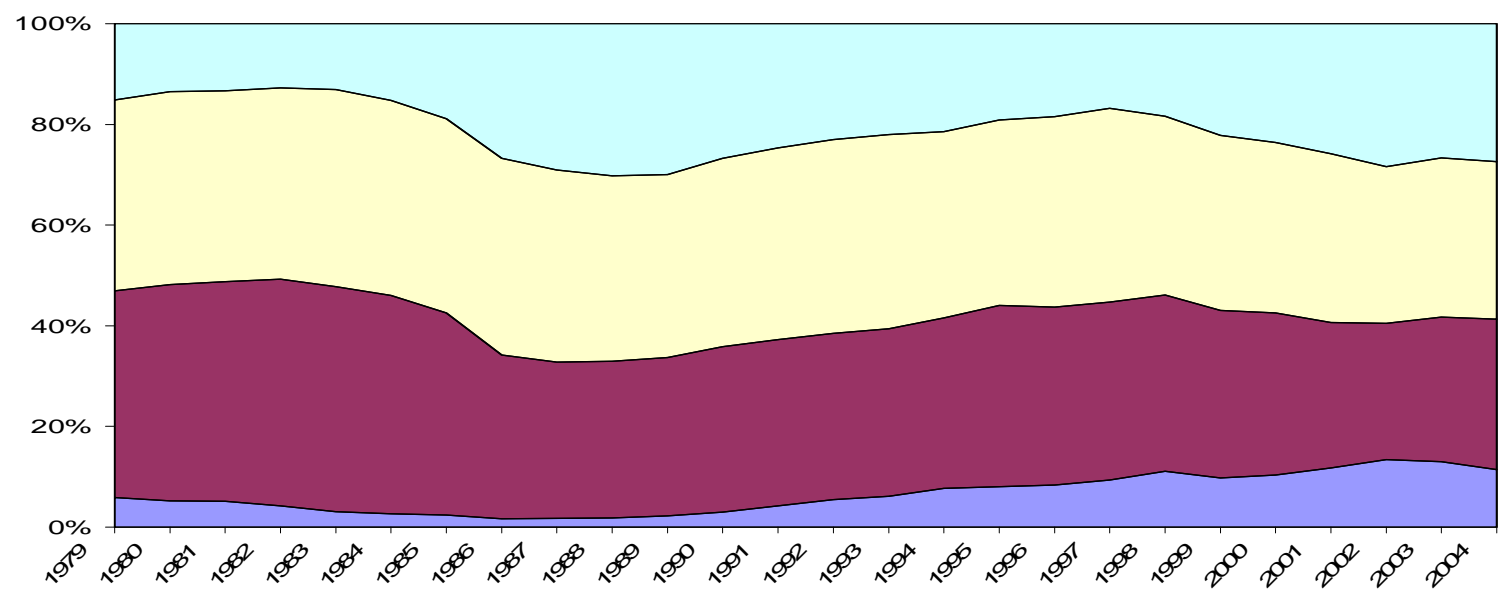

5c. Shares and other equities hold by financial intermediaries

Notes: Fund-raising by the Japanese domestic nonfinancial via, from bottom to top, public financial institutions, depository corporations, insurance and pension funds, other financial intermediaries and financial auxiliaries. Data: Flow of Funds Account - Bank of Japan. Outstandings on a book value basis. 


\subsection{Intermediation ratio of institutional sectors}

For NFC (Figure 6a), the total intermediation ratio decreases slightly. The credit intermediation ratio started to fall by the end of the 1980s and continued to decrease significantly throughout the 1990s. At the same time, the share of securities issued by NFC and acquired by FI increased from the end of the 1980s, but was not sufficient to compensate for the fall in bank credits. As a consequence, the NFC global ratio fell. However, one can note that the decrease did not exceed 10 points (between 1980 and 2000). These trends arise more clearly when one isolates the private NFC (the dotted lines): the credit intermediation ratio of private NFC falls from $78 \%$ in 1979 to $59 \%$ in 2004 (against $73 \%$ to $57 \%$ for all NFC) and the market intermediation ratio increases from $9 \%$ to $15 \%$ (against $14 \%$ to $18 \%$ for all NFC).

The decrease of the credit intermediation ratio is in accordance with the results obtained at the firm level by Hoshi \& Kashyap (1999) concerning the decrease of the ratio of bank debt to assets, at least for large firms (38\% in 1978, $28 \%$ in 1998, for all industries). The involvement of the banks in corporate governance also probably decreased with the relative fall of credit in external financing. But, because of the close relationship between market financings and intermediate financings, a securities issuance by a firm does not necessarily mean that this financing excludes banks or other financial intermediaries. In this way, firms remain dependent on intermediate financing.

For GOV (Figure 6b), the global ratio remains at around $80 \%$. The market intermediation ratio was already high (53\%) in 1979 and grew to reach 60\% in 2004. It seems that the modalities of public financing did not change significantly, whereas the need for external financing grew sharply with the public deficit. 
Figure 6a. Japanese intermediation ratios - Domestic Nonfinancial Corporations

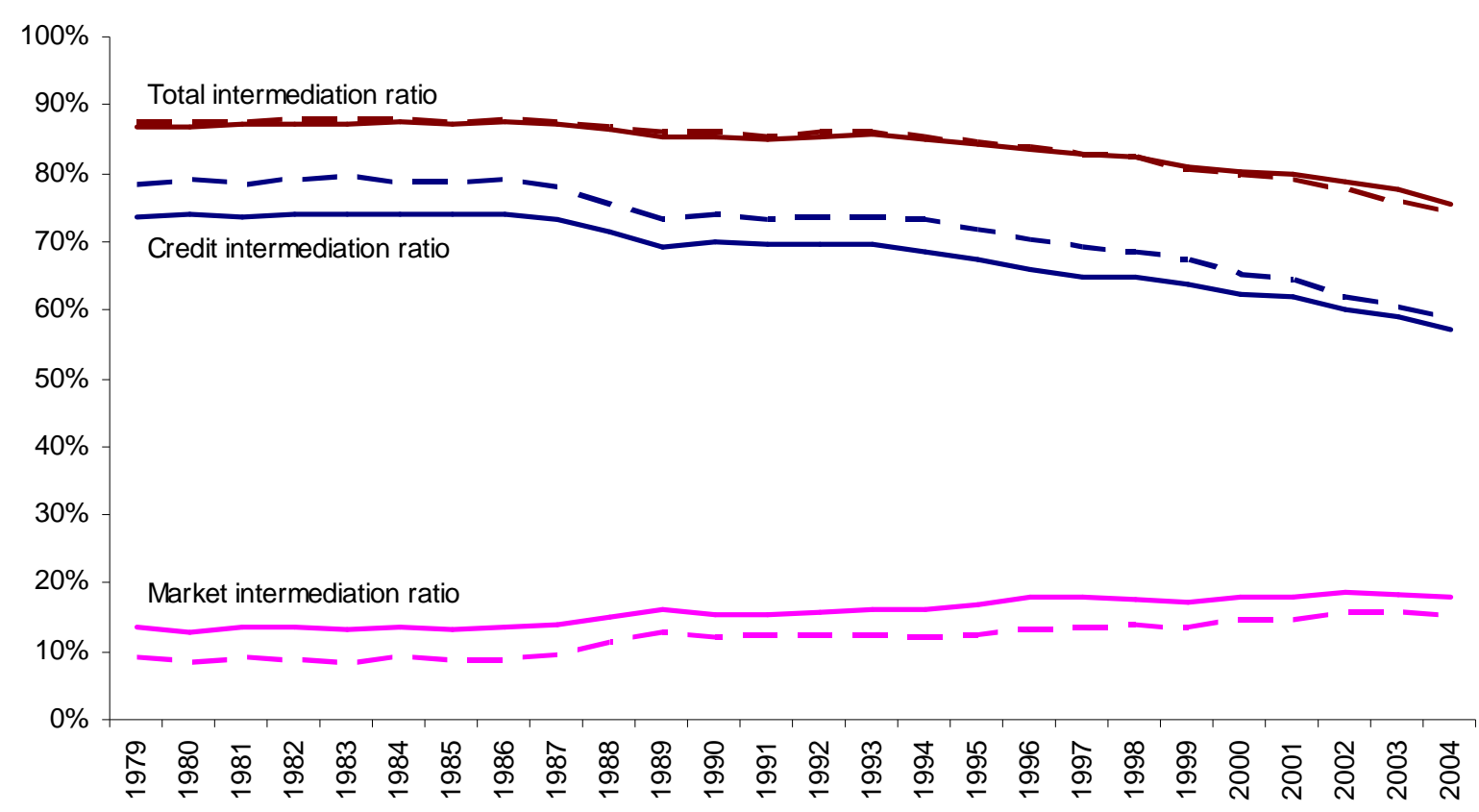

Figure 6b. Japanese intermediation ratios - General Government

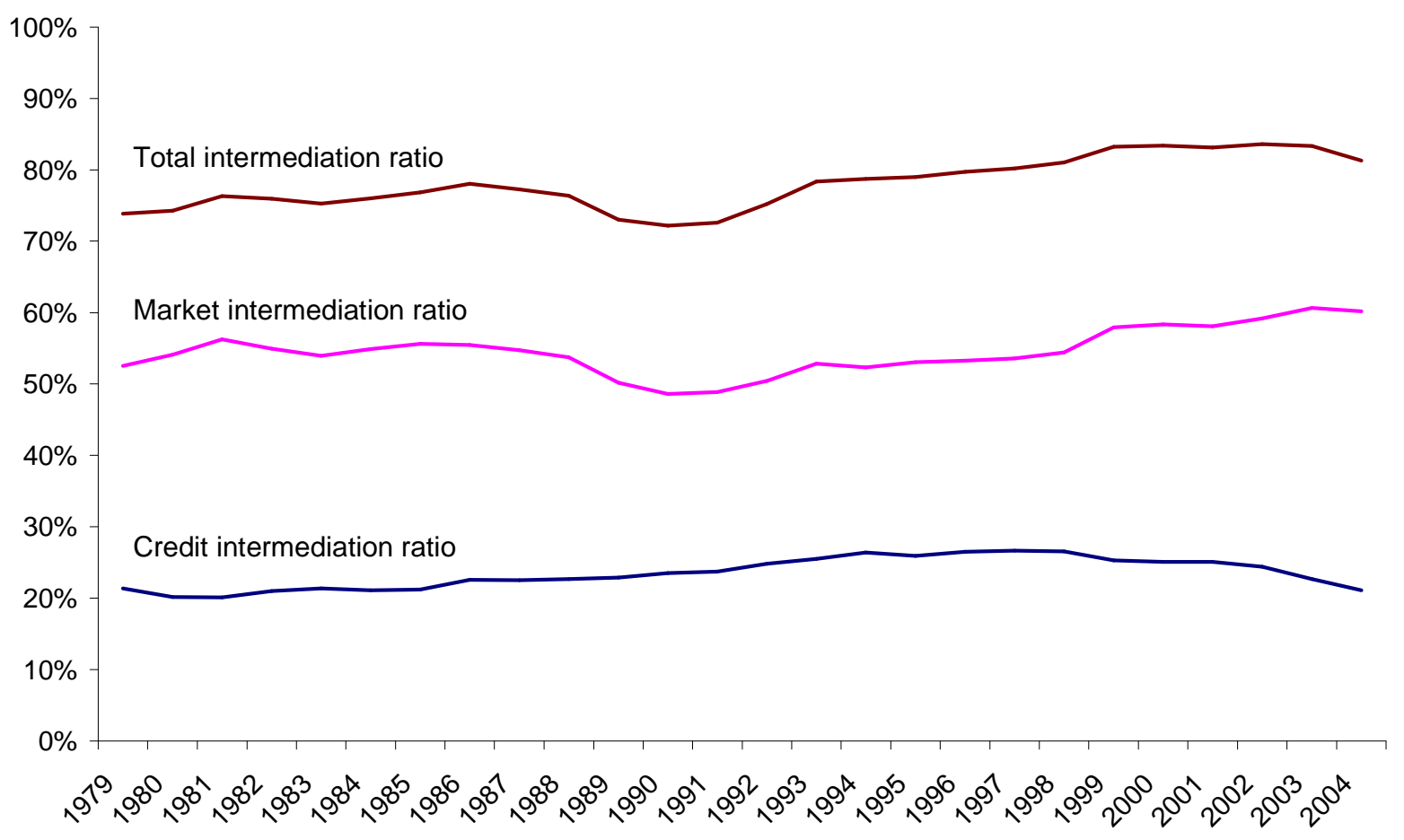

Notes. Total intermediation ratio $=$ (loans + securities held by financial intermediaries) $/$ external financing; Credit intermediation ratio $=$ loans $/$ external financing; Market intermediation ratio $=$ securities held by financial intermediaries / external financing. Data: Flow of Funds Account - Bank of Japan. Outstandings on a book value basis. Figure 5a: Private and public NFC (solid lines), private NFC (dotted lines). 


\subsection{The composition effect of external financings}

There was a significant modification in the composition of external financings in Japan between 1979 and 2004 (see Figure 7). NFC external financings increased until the early 1990s and declined thereafter, while GOV external financings were in a strong uptrend.

Consequently, the share of GOV in domestic external financing increased largely at the expense of the NFC share. This gives rise to a significant composition effect of external financings in the total evolution (see Figure 8). This composition effect amplifies both the decrease in the credit intermediation ratio and the increase in the market intermediation ratio. It is particularly significant for the market intermediation ratio. With an unchanged composition in external financing ${ }^{5}$, the credit intermediation ratio would have dropped by 14 points over the period instead of 27 , and the market intermediation ratio would have increased by 22 points instead of 42 (see Table 1). These shadow measures give the genuine extent, which is significantly lower, of the changes in financial behavior.

Table 1. Breakdown of the global evolution of intermediation ratios over the period

\begin{tabular}{lccc}
\hline \hline & Total evolution & Pure variation effect & Composition effect \\
\hline$\Delta$ Credit intermediation ratio & 0.73 & 0.86 & 0.84 \\
$\Delta$ Market intermediation ratio & 1.75 & 1.22 & 1.42 \\
\hline \hline
\end{tabular}

Notes: Multiplier coefficients of intermediation ratios between 1979 and 2004. For the credit intermediation ratio, $0.73=0.86 \times 0.84:$ the credit intermediation ratio decreased by $27 \%$ during the period and this total evolution combines an external financings composition effect as strong as the pure variation effect. For the market intermediation ratio, $1.75=1.22 \times 1.42$ : without change in the external financings composition, the market intermediation ratio would have increased by only $22 \%$.

\footnotetext{
5 We retain the composition of the beginning period (1979), that is $57 \%$ for NFC and $24 \%$ for GOV.
} 
Figure 7. External Financing by the Japanese Domestic Nonfinancial Sector

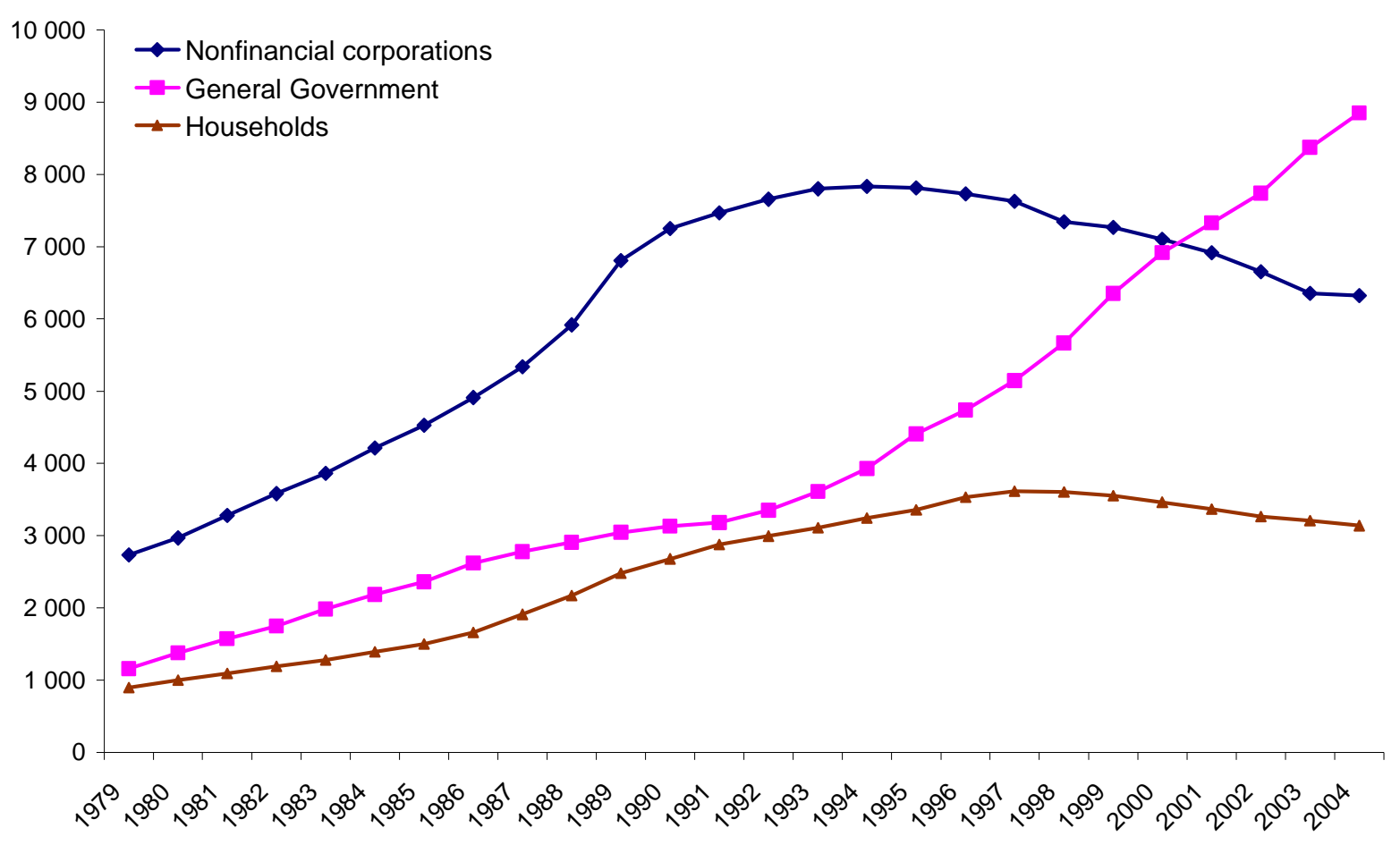

Figure 8. Japanese intermediation ratios

With and without change in the external financings composition

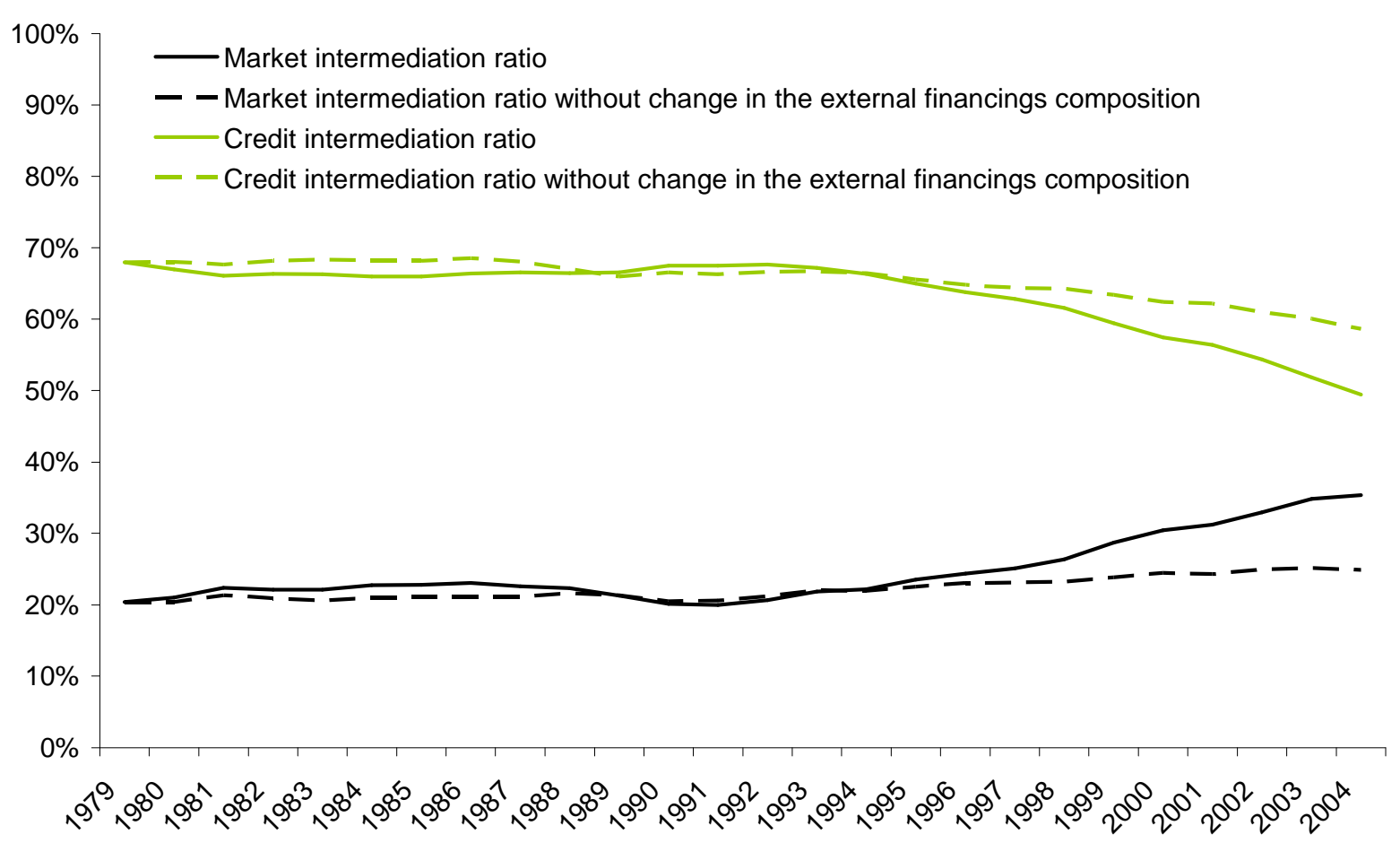

Notes: Credit intermediation ratio $=$ loans / external financing; Market intermediation ratio $=$ securities held by financial intermediaries / external financing. Data: Flow of Funds Account - Bank of Japan. Outstandings on a book value basis. 


\subsection{Intermediation ratios versus other indicators of the degree of financial intermediation}

Many indicators are used to assess financial development or to measure the relative weight of financial and banking intermediation. In addition to the three ratios computed above - the credit intermediation ratio (1a), the market intermediation ratio (1b), the total intermediation ratio (1c) others indicators can be considered (see Table 2).

Edey and Hviding (1995) ${ }^{6}$ use: the ratio of financial assets of all domestic sectors to GDP (2); the ratio of financial assets of financial institutions (including banks) to financial assets of all domestic sectors (3); the ratio of financial assets of the banking sector to financial assets of all financial institutions (4). In Rajan and Zingales (2003a, 2003b), three other indicators are used: the ratio of bank loans to the private sector and GDP (5); the ratio of commercial and savings bank deposits to GDP (6); the ratio of stock market capitalization to GDP (7). A last indicator is sometimes used which, however, measures the dynamics of capital markets more than financial development itself: the value of share trading, that is the total amount of transactions divided by GDP (8). ${ }^{7}$

The comparison of these various indicators calls for several observations. ${ }^{8}$

Only intermediation ratios say something about the financing structure: (2) measures the size of the financial sector; (3) gives the relative size of the financial intermediaries portfolio; (4) measures the weight of banks among the financial intermediaries; (5) and (6) measure more the level of the traditional banking activities than the relative importance of the banks compared to the capital markets in financing; (7) and (8) focus only on listed equities.

These indicators give a more or less broad vision of financial intermediation: (5) and (6) give a narrow vision of financial intermediation, like (1a); (3) measures only FI participation in market financings, like (1b); among all these indicators, only the total intermediation ratio (1c) offers a precise measurement of the weight of the banks (considered at the same time in their traditional activity of credit and their activity of claims investment) and other FI in the external financing of the DNF.

All these indicators do not capture the changing nature of intermediation: (5) and (6) seem to provide empirical evidence for the regular growth of traditional banking activities (credits and deposits) until 2000. This is rather puzzling given the analyses that stress the gravity of the banking crisis in Japan during the 1990-2000 period. The breakdown of the total intermediation ratio (1c) into a credit intermediation ratio (1a) and a market intermediation ratio (1b) shows more finely the contraction of credit and the correction enabled by the increase in market intermediation.

Indicators which are based on stock market data are very erratic. (7) and (8) are sensitive to changes in securities prices and have to be interpreted with caution. Moreover, these indicators are not exclusive of those referring to intermediation. In other words, the evolution of intermediation cannot be inferred by the evolution of the stock price index or, more broadly, of market activity.

\footnotetext{
6 Allen and Santomero (2001) also use such indicators.

7 The ratio of the number of domestic companies whose equities are publicly traded in Tokyo and Osaka and the country's population in millions varies between 23 in 1990 and 26 in 2003 (source: FIBV). The ratio of funds raised through public equity offerings (both initial public offerings and seasoned equity issues) by domestic companies to gross fixed capital formation cannot be computed because the required data are not available for Japan in the FIBV database.

8 Edey and Hviding (1995) use the OECD database. Rajan and Zingales (2003b) use data from Mitchell (1995): deposits and national income are extrapolated to 1999 for deposits by using the growth rate of deposits from the IMF's International Financial Statistics.
} 
Table 2. Various Indicators of the Japanese Financial System

\begin{tabular}{|c|c|c|c|c|c|}
\hline & $\begin{array}{l}\text { Data } \\
\text { source }\end{array}$ & 1980 & 1990 & 2000 & 2004 \\
\hline 1a) Credit intermediation ratio & BoJ & $67 \%$ & $67 \%$ & $57 \%$ & $49 \%$ \\
\hline 1b) Market intermediation ratio & BoJ & $21 \%$ & $20 \%$ & $30 \%$ & $35 \%$ \\
\hline 1c) Total intermediation ratio & BoJ & $88 \%$ & $88 \%$ & $88 \%$ & $85 \%$ \\
\hline 2) Financial assets of all domestic sectors/GDP & $\begin{array}{l}\text { BoJ, } \\
\text { IFS }\end{array}$ & 6.4 & 10.4 & 11.5 & 11.5 \\
\hline $\begin{array}{l}\text { 3) Financial assets of FI/financial assets of all } \\
\text { domestic sector }\end{array}$ & $\mathrm{BoJ}$ & $48 \%$ & $52 \%$ & $54 \%$ & $52 \%$ \\
\hline $\begin{array}{l}\text { 4) Financial assets of banking sector/ financial } \\
\text { assets of FI }\end{array}$ & BoJ & $62 \%$ & $57 \%$ & $51 \%$ & $50 \%$ \\
\hline 5) Bank loans to private sector/GDP & IFS & $83 \%$ & $119 \%$ & $115 \%$ & $100 \%$ \\
\hline 6) Deposits/GDP & IFS & $78 \%$ & $104 \%$ & $113 \%$ & $124 \%$ \\
\hline 7) Stock market capitalization/GDP & $\begin{array}{l}\text { FIBV, } \\
\text { IFS }\end{array}$ & na & $89 \%$ & $72 \%$ & $75 \%$ \\
\hline 8) Value of share trading/GDP & $\begin{array}{c}\text { FIBV, } \\
\text { IFS }\end{array}$ & na & $47 \%$ & $61 \%$ & $70 \%$ \\
\hline
\end{tabular}

Notes: Credit intermediation ratio $=$ loans / external financing; Market intermediation ratio $=$ securities held by financial intermediaries / external financing; Total intermediation ratio $=$ Credit intermediation ratio + Market intermediation ratio. 1a), 1b) and 1c) are expressed on a book value basis. What is called the "financial intermediation ratio" by Edey and Hviding (1995) is the ratio of financial assets of financial institutions (including banks) to financial assets of all domestic sectors. What they call the "bank intermediation ratio" is the ratio of assets of the banking sector (we consider deposit corporations) to assets of all financial institutions. "Financial assets" is the total of financial account asset. "Bank loans to the private sector over GDP" is the ratio of claims on the private sector of deposit money banks (IFS line 22d) and GDP (IFS line 99b). "Deposits over GDP" is the ratio of demand, time and savings deposits of deposit money banks (IFS lines 24, 25) and GDP. Stock market capitalization to GDP is the aggregate market value of the equity of domestic companies listed on the Tokyo Stock Exchange (FIBV) divided by GDP. Value of share trading is the total amount of transactions (Domestic \& Foreign, including Investment Funds) in Tokyo and Osaka divided by GDP. 


\section{Conclusion}

Our results show that the intermediation ratio in Japan remained quite stable between 1979 and 2004, at around $85 \%$. However, this stability is the result of two opposite trends: a contraction of credits and an increase in financial securities owned by financial (mostly public and non banking) institutions. We stressed also that the decrease in the credit intermediation ratio and the increase in the market intermediation ratio are not fully explained by a change in financial behaviors, but are also due to a composition effect of external financings: the decreasing share of corporations in the domestic non financial sector external financings makes the relative fall of loans stronger. Conversely, the increasing share of the general government sector accentuates the relative rise of securities in intermediate financings.

At the methodological level, one of the general results of this study is that the measurement of intermediation ratios must be done with outstandings (better suited than flows to long period analyses) corrected for stock price changes. If we had used data on a market value basis, one would show in periods of a strong fall of the Japanese stock market (early 1990s and early 2000s) an increasing, but actually artificial, intermediation ratio. Similarly, a computation using data on a market value basis would have emphasized an artificial disintermediation during the sharp rise in the Japanese stock market from 1980 to 1990. In this respect, a generalization of accounting standards concerning market value would make the measurement of the financings structures even more difficult. In any case a treatment of the data would have to be systematic.

Finally, on a theoretical level, by showing that intermediate financings increasingly consist in the purchasing of claims by financial intermediaries, our study confirms the close connection between market financings and intermediate financings and, in this respect, goes beyond the case of Japan. Concepts traditionally used to analyze the evolution of financial systems thus appear less and less operational. This is particularly true regarding the distinction between market (or direct) financing and intermediate (or indirect) financing, and between a bank-based system and a capital market-based system. Market financings are to a large extent intermediate and the orientation of the financial systems is basically mixed. Therefore, to characterize the structures of financing and their evolution over time, the relevant typology should be centered on intermediate financings between credit and claims investment by financial intermediaries. 


\section{References}

Allen F. and D. Gale, 2000, Comparing financial systems, MIT-Press, Cambridge.

Allen F. and A. M. Santomero, 2001, What do financial intermediaries do?, Journal of Banking and Finance, $25,271-294$.

Anderson C. W. and A. K. Makhija, 1999, Deregulation, disintermediation, and agency costs of debt: evidence from Japan, Journal of Financial Economics, 51 (1999) 309-339.

Beck Th., A. Demirgüç-Kunt and R. Levine, 2001, The financial structure database, in "Financial Structure and Economic Growth: A Cross-Country Comparison of Banks, Markets, and Development" (A. Demirguc-Kunt and R. Levine, Eds.), 17-80. MIT Press, Cambridge MA.

Boot A.W. and A.V. Thakor, 2000, Can relationship banking survive competition?, Journal of Finance, 55, 679-713.

Boyd J. and B.D. Smith, 1998, The evolution of debt and equity markets in economic development, Economic Theory, 12, 519-60.

Capelle-Blancard G. and J. Couppey-Soubeyran, 2003, Le financement des agents non financiers en Europe : le rôle des intermédiaires financiers demeure prépondérant, Economie et Statistique, 366, 6395.

Edey M. and K. Hviding, 1995, An assessment of financial reform in OECD countries, OECD Working Papers $\mathrm{n}^{\circ} 154$.

Hoshi T. and A. Kashyap, 1999, The Japanese banking crisis: Where did it come from and how will it end?, NBER Working Paper $n^{\circ} 7250$.

Kobayashi K., Y. Saita and T. Sekine, 2002, Forbearance lending: A case for Japanese firms, Bank of Japan Research and Statistics Department Working Paper, No. 02-2.

Levine R., 2002, Bank-based or market-based financial systems: Which is better? Journal of Financial Intermediation, 11(4), 398-428.

2005, Finance and Growth: Theory, Evidence, and Mechanisms, in Handbook of Economic Growth. Ph. Aghion and S. Durlauf (eds.), Amsterdam, North-Holland Elsevier Publishers.

Merton R.C. and Z. Bodie 1995, A Conceptual Framework, for Analyzing the Financial Environment, in "The Global Financial System: A Functional Perspective", Harvard Business School Press.

2004, The design of financial systems: Towards a synthesis of function and structure, NBER Working Papers, 10620, National Bureau of Economic Research, Inc.

Mitchell B., 1995, International Historical Statistics, Stockton Press, London.

Rajan R.G. and L. Zingales, 2003a, Banks and markets: The changing character of European finance, NBER Working Paper $\mathrm{n}^{\circ} 9595$.

2003b, The great reversals: The politics of financial development in the 20th century, Journal of Financial Economics, 69, 5-50.

Rousseau, P.L. and P. Wachtel, 2000, Equity markets and growth: Cross-country evidence on timing and outcomes, 1980-1995, Journal of Business and Finance, 24, 1933-1957.

Schmidt R.H., A. Hackethal and M. Tyrell, 1999, Disintermediation and the role of banks in Europe: An international comparison, Journal of Financial Intermediation, 8, 36-67.

Yamori N. and N. Nishigaki, 2005, The public financial system in Japan: Re-verification of the ballooning theory and the privileged government enterprise theory, Public Policy Review, 1(1), 33-48. 
Table A1: Financial intermediation ratios in Japan

\begin{tabular}{|c|c|c|c|c|c|c|c|c|c|c|c|c|c|}
\hline & 1979 & 1980 & 1981 & 1982 & 1983 & 1984 & 1985 & 1986 & 1987 & 1988 & 1989 & 1990 & 1991 \\
\hline External financing of domestic nonfinancial sectors $[=1+2+3+4]$ & 6,768 & 7,462 & 8,189 & 8,791 & 9,601 & 10,386 & 10,988 & 12,031 & 13,188 & 14,470 & 16,235 & 17,297 & 17,899 \\
\hline 1. Loans & 3,251 & 3,574 & 3,930 & 4,326 & 4,725 & 5,142 & 5,529 & 6,103 & 6,674 & 7,303 & 8,204 & 8,816 & 9,131 \\
\hline 1.A Via domestic financial institutions & 3,251 & 3,574 & 3,930 & 4,326 & 4,725 & 5,142 & 5,529 & 6,103 & 6,674 & 7,303 & 8,204 & 8,816 & 9,131 \\
\hline 1.A.1 Via public domestic financial institutions & 805 & 917 & 1,033 & 1,161 & 1,279 & 1,371 & 1,450 & 1,525 & 1,596 & 1,695 & 1,826 & 1,938 & 2,032 \\
\hline 1.A.2 Via private domestic financial institutions & 2,447 & 2,657 & 2,897 & 3,165 & 3,445 & 3,771 & 4,080 & 4,578 & 5,078 & 5,608 & 6,377 & 6,877 & 7,099 \\
\hline 1.A.2.1 Depository corporations & 2,189 & 2,355 & 2,559 & 2,772 & 2,991 & 3,257 & 3,499 & 3,911 & 4,259 & 4,645 & 5,094 & 5,385 & 5,604 \\
\hline 1.A.2.2 Insurance and pension funds & 162 & 189 & 208 & 228 & 241 & 260 & 277 & 286 & 309 & 349 & 413 & 502 & 569 \\
\hline 1.A.2.3 Other financial intermediaries & 95 & 113 & 130 & 165 & 214 & 254 & 304 & 381 & 510 & 614 & 870 & 991 & 926 \\
\hline 2. Securities other than shares & 1,214 & 1,409 & 1,616 & 1,767 & 1,941 & 2,156 & 2,271 & 2,460 & 2,647 & 2,876 & 3,181 & 3,230 & 3,309 \\
\hline 2.A Via domestic financial institutions & 914 & 1,052 & 1,248 & 1,347 & 1,482 & 1,664 & 1,783 & 1,974 & 2,097 & 2,254 & 2,382 & 2,373 & 2,425 \\
\hline 2.A.1.Via public domestic financial institutions & 291 & 362 & 445 & 443 & 473 & 562 & 610 & 707 & 839 & 941 & 1,048 & 1,086 & 1,133 \\
\hline 2.A.2 Via private domestic financial institutions & 623 & 690 & 804 & 904 & 1,009 & 1,102 & 1,174 & 1,267 & 1,258 & 1,313 & 1,334 & 1,288 & 1,292 \\
\hline 2.A.2.1 Depository corporations & 385 & 394 & 460 & 510 & 556 & 598 & 617 & 642 & 616 & 653 & 690 & 653 & 615 \\
\hline 2.A.2.2 Insurance and pension funds & 101 & 115 & 133 & 153 & 174 & 194 & 208 & 225 & 232 & 251 & 250 & 245 & 245 \\
\hline 2.A.2.3 Other financial intermediaries & 137 & 180 & 210 & 241 & 279 & 310 & 348 & 400 & 411 & 409 & 394 & 389 & 432 \\
\hline 2.B Via domestic nonfinancial sectors & 185 & 250 & 229 & 270 & 303 & 303 & 333 & 326 & 345 & 377 & 392 & 424 & 400 \\
\hline 2.C Via overseas & 116 & 107 & 139 & 150 & 156 & 189 & 155 & 161 & 206 & 245 & 406 & 433 & 484 \\
\hline 3. Shares and other equities & 318 & 354 & 397 & 427 & 458 & 494 & 581 & 627 & 704 & 812 & 945 & 1,016 & 1,086 \\
\hline 3.A Via domestic financial institutions & 63 & 71 & 82 & 94 & 97 & 109 & 131 & 148 & 165 & 201 & 243 & 261 & 279 \\
\hline 3.A.1.Via public domestic financial institutions & 4 & 4 & 4 & 4 & 3 & 3 & 3 & 2 & 3 & 4 & 5 & 8 & 12 \\
\hline 3.A.2 Via private domestic financial institutions & 59 & 67 & 78 & 90 & 94 & 106 & 128 & 146 & 163 & 197 & 238 & 253 & 267 \\
\hline 3.A.2.1 Depository corporations & 26 & 31 & 36 & 42 & 43 & 47 & 53 & 48 & 51 & 62 & 77 & 86 & 92 \\
\hline 3.A.2.2 Insurance and pension funds & 24 & 27 & 31 & 36 & 38 & 42 & 51 & 58 & 63 & 74 & 88 & 98 & 106 \\
\hline 3.A.2.3 Other financial intermediaries & 10 & 10 & 11 & 12 & 13 & 17 & 25 & 40 & 48 & 61 & 73 & 70 & 69 \\
\hline 3.B Via domestic nonfinancial sectors & 251 & 273 & 302 & 317 & 342 & 366 & 429 & 461 & 524 & 593 & 678 & 726 & 768 \\
\hline 3.C Via overseas & 4 & 10 & 12 & 16 & 20 & 19 & 21 & 18 & 15 & 19 & 24 & 28 & 39 \\
\hline 4. Trade credits & 1,984 & 2,125 & 2,245 & 2,272 & 2,477 & 2,595 & 2,606 & 2,841 & 3,162 & 3,479 & 3,905 & 4,235 & 4,374 \\
\hline Credit intermediation ratio $[=1 /(1+2+3)]$ & $68 \%$ & $67 \%$ & $66 \%$ & $66 \%$ & $66 \%$ & $66 \%$ & $66 \%$ & $66 \%$ & $67 \%$ & $66 \%$ & $67 \%$ & $67 \%$ & $68 \%$ \\
\hline Market intermediation ratio $[=(2 \mathrm{~A}+3 \mathrm{~A}) /(1+2+3)]$ & $20 \%$ & $21 \%$ & $22 \%$ & $22 \%$ & $22 \%$ & $23 \%$ & $23 \%$ & $23 \%$ & $23 \%$ & $22 \%$ & $21 \%$ & $20 \%$ & $20 \%$ \\
\hline Total intermediation ratio $[=(1+2 \mathrm{~A}+3 \mathrm{~A}) /(1+2+3)]$ & $88 \%$ & $88 \%$ & $89 \%$ & $88 \%$ & $88 \%$ & $89 \%$ & $89 \%$ & $89 \%$ & $89 \%$ & $89 \%$ & $88 \%$ & $88 \%$ & $87 \%$ \\
\hline
\end{tabular}

Data: Flow of Funds Account - Bank of Japan. Outstandings on a book value basis. Units: JPY 100,000 millions or \%. 
Table A1: Financial intermediation ratios in Japan (continued)

\begin{tabular}{|c|c|c|c|c|c|c|c|c|c|c|c|c|c|}
\hline & 1992 & 1993 & 1994 & 1995 & 1996 & 1997 & 1998 & 1999 & 2000 & 2001 & 2002 & 2003 & 2004 \\
\hline External financing of domestic nonfinancial sectors $[=1+2+3+4]$ & 18,132 & 18,640 & 19,252 & 20,386 & 20,740 & 20,978 & 20,841 & 21,379 & 21,743 & 21,668 & 21,706 & 21,932 & 22,338 \\
\hline 1. Loans & 9,468 & 9,754 & 9,959 & 10,125 & 10,211 & 10,292 & 10,232 & 10,206 & 10,042 & 9,932 & 9,603 & 9,295 & 9,054 \\
\hline 1.A Via domestic financial institutions & 9,468 & 9,754 & 9,959 & 10,125 & 10,211 & 10,292 & 10,232 & 10,206 & 10,042 & 9,932 & 9,603 & 9,295 & 9,054 \\
\hline 1.A.1 Via public domestic financial institutions & 2,183 & 2,426 & 2,658 & 2,761 & 2,930 & 3,040 & 3,106 & 3,293 & 3,346 & 3,363 & 3,306 & 3,175 & 3,069 \\
\hline 1.A.2 Via private domestic financial institutions & 7,285 & 7,328 & 7,301 & 7,364 & 7,281 & 7,252 & 7,126 & 6,913 & 6,696 & 6,569 & 6,298 & 6,119 & 5,985 \\
\hline 1.A.2.1 Depository corporations & 5,782 & 5,820 & 5,830 & 5,953 & 5,980 & 5,965 & 5,836 & 5,703 & 5,601 & 5,477 & 5,171 & 5,013 & 4,892 \\
\hline 1.A.2.2 Insurance and pension funds & 617 & 636 & 652 & 641 & 627 & 600 & 566 & 533 & 482 & 456 & 436 & 409 & 377 \\
\hline 1.A.2.3 Other financial intermediaries & 887 & 872 & 819 & 770 & 674 & 687 & 724 & 676 & 614 & 636 & 691 & 697 & 717 \\
\hline 2. Securities other than shares & 3,420 & 3,598 & 3,830 & 4,195 & 4,498 & 4,760 & 5,029 & 5,502 & 5,922 & 6,140 & 6,485 & 7,107 & 7,618 \\
\hline 2.A Via domestic financial institutions & 2,610 & 2,875 & 3,042 & 3,382 & 3,607 & 3,829 & 4,085 & 4,669 & 5,026 & 5,188 & 5,506 & 5,976 & 6,190 \\
\hline 2.A.1.Via public domestic financial institutions & 1,228 & 1,356 & 1,407 & 1,642 & 1,785 & 1,973 & 2,162 & 2,127 & 2,015 & 2,445 & 2,552 & 2,679 & 2,731 \\
\hline 2.A.2 Via private domestic financial institutions & 1,382 & 1,519 & 1,635 & 1,740 & 1,822 & 1,856 & 1,923 & 2,543 & 3,011 & 2,744 & 2,954 & 3,297 & 3,459 \\
\hline 2.A.2.1 Depository corporations & 639 & 704 & 745 & 744 & 745 & 762 & 824 & 1,103 & 1,352 & 1,264 & 1,403 & 1,729 & 1,825 \\
\hline 2.A.2.2 Insurance and pension funds & 276 & 333 & 410 & 498 & 561 & 589 & 615 & 789 & 924 & 900 & 949 & 1,020 & 1,063 \\
\hline 2.A.2.3 Other financial intermediaries & 467 & 481 & 481 & 497 & 516 & 504 & 484 & 651 & 735 & 580 & 601 & 548 & 571 \\
\hline 2.B Via domestic nonfinancial sectors & 405 & 383 & 488 & 498 & 555 & 583 & 554 & 532 & 558 & 684 & 689 & 809 & 1,038 \\
\hline 2.C Via overseas & 404 & 340 & 299 & 315 & 336 & 348 & 390 & 300 & 339 & 268 & 290 & 323 & 390 \\
\hline 3. Shares and other equities & 1,109 & 1,167 & 1,213 & 1,255 & 1,294 & 1,335 & 1,354 & 1,466 & 1,517 & 1,540 & 1,571 & 1,532 & 1,642 \\
\hline 3.A Via domestic financial institutions & 285 & 299 & 286 & 281 & 296 & 285 & 296 & 266 & 295 & 309 & 317 & 271 & 283 \\
\hline 3.A.1.Via public domestic financial institutions & 16 & 18 & 22 & 23 & 25 & 27 & 33 & 26 & 31 & 36 & 43 & 35 & 32 \\
\hline 3.A.2 Via private domestic financial institutions & 270 & 281 & 264 & 258 & 271 & 258 & 263 & 240 & 264 & 273 & 275 & 236 & 251 \\
\hline 3.A.2.1 Depository corporations & 94 & 99 & 97 & 101 & 105 & 101 & 104 & 88 & 95 & 89 & 86 & 78 & 85 \\
\hline 3.A.2.2 Insurance and pension funds & 110 & 115 & 106 & 104 & 112 & 110 & 105 & 93 & 100 & 104 & 99 & 86 & 89 \\
\hline 3.A.2.3 Other financial intermediaries & 66 & 66 & 61 & 54 & 55 & 48 & 54 & 59 & 70 & 80 & 90 & 72 & 78 \\
\hline 3.B Via domestic nonfinancial sectors & 782 & 814 & 873 & 902 & 914 & 961 & 947 & 1,034 & 1,068 & 1,074 & 1,102 & 1,072 & 1,139 \\
\hline 3.C Via overseas & 42 & 54 & 54 & 72 & 83 & 89 & 111 & 166 & 154 & 157 & 152 & 189 & 219 \\
\hline 4. Trade credits & 4,135 & 4,121 & 4,250 & 4,811 & 4,738 & 4,590 & 4,226 & 4,206 & 4,262 & 4,056 & 4,047 & 3,998 & 4,024 \\
\hline Credit intermediation ratio $[=1 /(1+2+3)]$ & $68 \%$ & $67 \%$ & $66 \%$ & $65 \%$ & $64 \%$ & $63 \%$ & $62 \%$ & $59 \%$ & $57 \%$ & $56 \%$ & $54 \%$ & $52 \%$ & $49 \%$ \\
\hline Market intermediation ratio $[=(2 \mathrm{~A}+3 \mathrm{~A}) /(1+2+3)]$ & $21 \%$ & $22 \%$ & $22 \%$ & $24 \%$ & $24 \%$ & $25 \%$ & $26 \%$ & $29 \%$ & $30 \%$ & $31 \%$ & $33 \%$ & $35 \%$ & $35 \%$ \\
\hline Total intermediation ratio $[=(1+2 \mathrm{~A}+3 \mathrm{~A}) /(1+2+3)]$ & $88 \%$ & $89 \%$ & $89 \%$ & $89 \%$ & $88 \%$ & $88 \%$ & $88 \%$ & $88 \%$ & $88 \%$ & $88 \%$ & $87 \%$ & $87 \%$ & $85 \%$ \\
\hline
\end{tabular}

Data: Flow of Funds Account - Bank of Japan. Outstandings on a book value basis. Units: JPY 100,000 millions or \%. 
Table A2: Financial intermediation ratios in Japan - Domestic nonfinancial corporations

\begin{tabular}{|c|c|c|c|c|c|c|c|c|c|c|c|c|c|}
\hline & 1979 & 1980 & 1981 & 1982 & 1983 & 1984 & 1985 & 1986 & 1987 & 1988 & 1989 & 1990 & 1991 \\
\hline External financing of domestic nonfinancial corporations $[=1+2+3+4]$ & 4,275 & 4,622 & 5,015 & 5,287 & 5,710 & 6,143 & 6,415 & 7,009 & 7,740 & 8,566 & 9,809 & 10,521 & 10,923 \\
\hline 1. Loans via domestic financial institutions & 2,008 & 2,199 & 2,411 & 2,648 & 2,865 & 3,120 & 3,345 & 3,634 & 3,907 & 4,221 & 4,722 & 5,078 & 5,195 \\
\hline 1.A.1 Via public financial institutions & 392 & 442 & 491 & 535 & 573 & 608 & 632 & 596 & 592 & 617 & 666 & 689 & 730 \\
\hline 1.A.2 Via private financial institutions & 1,616 & 1,757 & 1,921 & 2,113 & 2,292 & 2,512 & 2,713 & 3,038 & 3,314 & 3,603 & 4,056 & 4,389 & 4,465 \\
\hline 2. Securities other than shares & 407 & 414 & 471 & 506 & 541 & 602 & 599 & 649 & 728 & 883 & 1,140 & 1,159 & 1,189 \\
\hline 2A. Via domestic financial institutions & 306 & 309 & 364 & 386 & 413 & 465 & 471 & 521 & 577 & 692 & 854 & 851 & 871 \\
\hline 3. Shares and other equities & 318 & 354 & 397 & 427 & 458 & 494 & 581 & 627 & 704 & 812 & 945 & 1,016 & 1,086 \\
\hline 3A. Via domestic financial institutions & 63 & 71 & 82 & 94 & 97 & 109 & 131 & 148 & 165 & 201 & 243 & 261 & 279 \\
\hline 4. Trade credits c) & 1,542 & 1,655 & 1,735 & 1,706 & 1,846 & 1,928 & 1,889 & 2,099 & 2,401 & 2,649 & 3,001 & 3,268 & 3,453 \\
\hline Credit intermediation ratio $[=1 /(1+2+3)]$ & $73 \%$ & $74 \%$ & $74 \%$ & $74 \%$ & $74 \%$ & $74 \%$ & $74 \%$ & $74 \%$ & $73 \%$ & $71 \%$ & $69 \%$ & $70 \%$ & $70 \%$ \\
\hline Market intermediation ratio $[=(2 \mathrm{~A}+3 \mathrm{~A}) /(1+2+3)]$ & $14 \%$ & $13 \%$ & $14 \%$ & $13 \%$ & $13 \%$ & $14 \%$ & $13 \%$ & $14 \%$ & $14 \%$ & $15 \%$ & $16 \%$ & $15 \%$ & $15 \%$ \\
\hline Total intermediation ratio $[=(1+2 \mathrm{~A}+3 \mathrm{~A}) /(1+2+3)]$ & $87 \%$ & $87 \%$ & $87 \%$ & $87 \%$ & $87 \%$ & $88 \%$ & $87 \%$ & $88 \%$ & $87 \%$ & $86 \%$ & $85 \%$ & $85 \%$ & $85 \%$ \\
\hline
\end{tabular}

\begin{tabular}{|c|c|c|c|c|c|c|c|c|c|c|c|c|c|}
\hline & 1992 & 1993 & 1994 & 1995 & 1996 & 1997 & 1998 & 1999 & 2000 & 2001 & 2002 & 2003 & 2004 \\
\hline External financing of domestic nonfinancial corporations $[=1+2+3+4]$ & 10,913 & 11,084 & 11,189 & 11,639 & 11,590 & 11,389 & 10,718 & 10,578 & 10,418 & 10,019 & 9,724 & 9,418 & 9,366 \\
\hline 1. Loans via domestic financial institutions & 5,341 & 5,424 & 5,378 & 5,262 & 5,086 & 4,957 & 4,760 & 4,639 & 4,419 & 4,272 & 3,995 & 3,756 & 3,619 \\
\hline 1.A.1 Via public financial institutions & 763 & 840 & 876 & 881 & 890 & 862 & 831 & 854 & 852 & 889 & 889 & 868 & 849 \\
\hline 1.A.2 Via private financial institutions & 4,578 & 4,584 & 4,501 & 4,381 & 4,196 & 4,095 & 3,929 & 3,785 & 3,568 & 3,384 & 3,106 & 2,888 & 2,770 \\
\hline 2. Securities other than shares & 1,208 & 1,210 & 1,241 & 1,296 & 1,352 & 1,334 & 1,232 & 1,164 & 1,167 & 1,104 & 1,089 & 1,065 & 1,062 \\
\hline 2A. Via domestic financial institutions & 922 & 967 & 986 & 1,045 & 1,084 & 1,073 & 1,001 & 988 & 990 & 933 & 924 & 895 & 863 \\
\hline 3. Shares and other equities & 1,109 & 1,167 & 1,213 & 1,255 & 1,294 & 1,335 & 1,354 & 1,466 & 1,517 & 1,540 & 1,571 & 1,532 & 1,642 \\
\hline 3A. Via domestic financial institutions & 285 & 299 & 286 & 281 & 296 & 285 & 296 & 266 & 295 & 309 & 317 & 271 & 283 \\
\hline 4. Trade credits & 3,256 & 3,283 & 3,356 & 3,826 & 3,859 & 3,762 & 3,372 & 3,309 & 3,315 & 3,104 & 3,070 & 3,065 & 3,044 \\
\hline Credit intermediation ratio $[=1 /(1+2+3)]$ & $70 \%$ & $70 \%$ & $69 \%$ & $67 \%$ & $66 \%$ & $65 \%$ & $65 \%$ & $64 \%$ & $62 \%$ & $62 \%$ & $60 \%$ & $59 \%$ & $57 \%$ \\
\hline Market intermediation ratio $[=(2 \mathrm{~A}+3 \mathrm{~A}) /(1+2+3)]$ & $16 \%$ & $16 \%$ & $16 \%$ & $17 \%$ & $18 \%$ & $18 \%$ & $18 \%$ & $17 \%$ & $18 \%$ & $18 \%$ & $19 \%$ & $18 \%$ & $18 \%$ \\
\hline Total intermediation ratio $[=(1+2 \mathrm{~A}+3 \mathrm{~A}) /(1+2+3)]$ & $86 \%$ & $86 \%$ & $85 \%$ & $84 \%$ & $84 \%$ & $83 \%$ & $82 \%$ & $81 \%$ & $80 \%$ & $80 \%$ & $79 \%$ & $77 \%$ & $75 \%$ \\
\hline
\end{tabular}

Data: Flow of Funds Account - Bank of Japan. Outstandings on a book value basis. Units: JPY 100,000 millions or \%. 
Table A3: Financial intermediation ratios in Japan - Private nonfinancial corporations

\begin{tabular}{|c|c|c|c|c|c|c|c|c|c|c|c|c|c|}
\hline & 1979 & 1980 & 1981 & 1982 & 1983 & 1984 & 1985 & 1986 & 1987 & 1988 & 1989 & 1990 & 1991 \\
\hline External financing of private nonfinancial corporations $[=1+2+3+4]$ & 3,823 & 4,117 & 4,454 & 4,671 & 5,038 & 5,432 & 5,662 & 6,268 & 6,976 & 7,777 & 8,964 & 9,651 & 10,092 \\
\hline 1. Loans via domestic financial institutions & 1,787 & 1,947 & 2,132 & 2,341 & 2,533 & 2,766 & 2,973 & 3,298 & 3,565 & 3,870 & 4,359 & 4,717 & 4,857 \\
\hline 1.A.1 Via public financial institutions & 171 & 191 & 211 & 228 & 240 & 254 & 260 & 259 & 251 & 267 & 303 & 328 & 392 \\
\hline 1.A.2 Via private financial institutions & 1,616 & 1,757 & 1,921 & 2,113 & 2,292 & 2,512 & 2,713 & 3,038 & 3,314 & 3,603 & 4,056 & 4,389 & 4,465 \\
\hline 2. Securities other than shares & 201 & 189 & 222 & 233 & 240 & 287 & 264 & 293 & 357 & 501 & 718 & 715 & 764 \\
\hline 2A. Via domestic financial institutions & 151 & 141 & 172 & 178 & 184 & 222 & 207 & 235 & 283 & 392 & 538 & 525 & 560 \\
\hline 3. Shares and other equities & 294 & 326 & 365 & 391 & 419 & 451 & 536 & 579 & 652 & 757 & 885 & 952 & 1,018 \\
\hline 3A. Via domestic financial institutions & 58 & 65 & 76 & 86 & 88 & 99 & 121 & 137 & 153 & 187 & 228 & 245 & 261 \\
\hline 4. Trade credits $c)$ & 1,542 & 1,655 & 1,735 & 1,706 & 1,846 & 1,928 & 1,889 & 2,099 & 2,401 & 2,649 & 3,001 & 3,268 & 3,453 \\
\hline Credit intermediation ratio $[=1 /(1+2+3)]$ & $78 \%$ & $79 \%$ & $78 \%$ & $79 \%$ & $79 \%$ & $79 \%$ & $79 \%$ & $79 \%$ & $78 \%$ & $75 \%$ & $73 \%$ & $74 \%$ & $73 \%$ \\
\hline Market intermediation ratio $[=(2 \mathrm{~A}+3 \mathrm{~A}) /(1+2+3)]$ & $9 \%$ & $8 \%$ & $9 \%$ & $9 \%$ & $9 \%$ & $9 \%$ & $9 \%$ & $9 \%$ & $10 \%$ & $11 \%$ & $13 \%$ & $12 \%$ & $12 \%$ \\
\hline Total intermediation ratio $[=(1+2 \mathrm{~A}+3 \mathrm{~A}) /(1+2+3)]$ & $88 \%$ & $87 \%$ & $88 \%$ & $88 \%$ & $88 \%$ & $88 \%$ & $87 \%$ & $88 \%$ & $87 \%$ & $87 \%$ & $86 \%$ & $86 \%$ & $86 \%$ \\
\hline
\end{tabular}

\begin{tabular}{|c|c|c|c|c|c|c|c|c|c|c|c|c|c|}
\hline & 1992 & 1993 & 1994 & 1995 & 1996 & 1997 & 1998 & 1999 & 2000 & 2001 & 2002 & 2003 & 2004 \\
\hline External financing of private nonfinancial corporations $[=1+2+3+4]$ & 10,031 & 10,145 & 10,194 & 10,602 & 10,514 & 10,320 & 9,774 & 9,612 & 9,452 & 9,017 & 8,722 & 8,480 & 8,339 \\
\hline 1. Loans via domestic financial institutions & 4,991 & 5,058 & 5,000 & 4,874 & 4,687 & 4,545 & 4,393 & 4,241 & 4,006 & 3,805 & 3,499 & 3,267 & 3,123 \\
\hline 1.A.1 Via public financial institutions & 413 & 474 & 499 & 494 & 491 & 450 & 464 & 456 & 438 & 421 & 393 & 379 & 353 \\
\hline 1.A.2 Via private financial institutions & 4,578 & 4,584 & 4,501 & 4,381 & 4,196 & 4,095 & 3,929 & 3,785 & 3,568 & 3,384 & 3,106 & 2,888 & 2,770 \\
\hline 2. Securities other than shares & 746 & 714 & 706 & 734 & 765 & 773 & 757 & 703 & 725 & 702 & 715 & 697 & 674 \\
\hline 2A. Via domestic financial institutions & 570 & 571 & 561 & 592 & 613 & 622 & 615 & 596 & 616 & 593 & 607 & 586 & 548 \\
\hline 3. Shares and other equities & 1,038 & 1,090 & 1,132 & 1,168 & 1,203 & 1,240 & 1,252 & 1,359 & 1,405 & 1,407 & 1,439 & 1,450 & 1,498 \\
\hline 3A. Via domestic financial institutions & 267 & 279 & 267 & 262 & 275 & 265 & 274 & 247 & 273 & 282 & 291 & 257 & 259 \\
\hline 4. Trade credits & 3,256 & 3,283 & 3,356 & 3,826 & 3,859 & 3,762 & 3,372 & 3,309 & 3,315 & 3,104 & 3,070 & 3,065 & 3,044 \\
\hline Credit intermediation ratio $[=1 /(1+2+3)]$ & $74 \%$ & $74 \%$ & $73 \%$ & $72 \%$ & $70 \%$ & $69 \%$ & $69 \%$ & $67 \%$ & $65 \%$ & $64 \%$ & $62 \%$ & $60 \%$ & $59 \%$ \\
\hline Market intermediation ratio $[=(2 \mathrm{~A}+3 \mathrm{~A}) /(1+2+3)]$ & $12 \%$ & $12 \%$ & $12 \%$ & $13 \%$ & $13 \%$ & $14 \%$ & $14 \%$ & $13 \%$ & $14 \%$ & $15 \%$ & $16 \%$ & $16 \%$ & $15 \%$ \\
\hline Total intermediation ratio $[=(1+2 \mathrm{~A}+3 \mathrm{~A}) /(1+2+3)]$ & $86 \%$ & $86 \%$ & $85 \%$ & $85 \%$ & $84 \%$ & $83 \%$ & $82 \%$ & $81 \%$ & $80 \%$ & $79 \%$ & $78 \%$ & $76 \%$ & $74 \%$ \\
\hline
\end{tabular}

Data: Flow of Funds Account - Bank of Japan. Outstandings on a book value basis. Units: JPY 100,000 millions or \%. 
Table A4: Financial intermediation ratios in Japan - General government

\begin{tabular}{|c|c|c|c|c|c|c|c|c|c|c|c|c|c|}
\hline & 1979 & 1980 & 1981 & 1982 & 1983 & 1984 & 1985 & 1986 & 1987 & 1988 & 1989 & 1990 & 1991 \\
\hline External financing of general government $[=1+2]$ & 1,157 & 1,374 & 1,573 & 1,750 & 1,982 & 2,184 & 2,358 & 2,620 & 2,778 & 2,906 & 3,046 & 3,130 & 3,178 \\
\hline 1. Loans via domestic financial institutions & 247 & 277 & 316 & 367 & 423 & 460 & 500 & 592 & 625 & 659 & 696 & 737 & 754 \\
\hline 1.A.1 Via public financial institutions & 231 & 255 & 286 & 330 & 376 & 402 & 431 & 516 & 558 & 591 & 629 & 668 & 677 \\
\hline 1.A.2 Via private financial institutions & 16 & 22 & 31 & 37 & 47 & 58 & 69 & 75 & 67 & 68 & 67 & 69 & 77 \\
\hline 2. Securities other than shares & 808 & 995 & 1,145 & 1,261 & 1,401 & 1,554 & 1,672 & 1,811 & 1,919 & 1,993 & 2,041 & 2,071 & 2,120 \\
\hline 2A. Via domestic financial institutions & 608 & 743 & 884 & 961 & 1,069 & 1,199 & 1,313 & 1,453 & 1,520 & 1,561 & 1,528 & 1,522 & 1,554 \\
\hline Credit intermediation ratio $[=1 /(1+2+3)]$ & $21 \%$ & $20 \%$ & $20 \%$ & $21 \%$ & $21 \%$ & $21 \%$ & $21 \%$ & $23 \%$ & $23 \%$ & $23 \%$ & $23 \%$ & $24 \%$ & $24 \%$ \\
\hline Market intermediation ratio $[=(2 \mathrm{~A}+3 \mathrm{~A}) /(1+2+3)]$ & $53 \%$ & $54 \%$ & $56 \%$ & $55 \%$ & $54 \%$ & $55 \%$ & $56 \%$ & $55 \%$ & $55 \%$ & $54 \%$ & $50 \%$ & $49 \%$ & $49 \%$ \\
\hline Total intermediation ratio $[=(1+2 \mathrm{~A}+3 \mathrm{~A}) /(1+2+3)]$ & $74 \%$ & $74 \%$ & $76 \%$ & $76 \%$ & $75 \%$ & $76 \%$ & $77 \%$ & $78 \%$ & $77 \%$ & $76 \%$ & $73 \%$ & $72 \%$ & $73 \%$ \\
\hline
\end{tabular}

\begin{tabular}{|c|c|c|c|c|c|c|c|c|c|c|c|c|c|}
\hline & 1992 & 1993 & 1994 & 1995 & 1996 & 1997 & 1998 & 1999 & 2000 & 2001 & 2002 & 2003 & 2004 \\
\hline External financing of general government $[=1+2]$ & 3,348 & 3,610 & 3,927 & 4,406 & 4,738 & 5,146 & 5,666 & 6,353 & 6,917 & 7,330 & 7,741 & 8,375 & 8,853 \\
\hline 1. Loans via domestic financial institutions & 830 & 920 & 1,036 & 1,143 & 1,255 & 1,370 & 1,506 & 1,607 & 1,733 & 1,838 & 1,890 & 1,897 & 1,869 \\
\hline 1.A.1 Via public financial institutions & 749 & 830 & 938 & 1,041 & 1,145 & 1,249 & 1,345 & 1,486 & 1,542 & 1,553 & 1,568 & 1,538 & 1,512 \\
\hline 1.A.2 Via private financial institutions & 81 & 90 & 98 & 102 & 110 & 121 & 161 & 121 & 191 & 285 & 321 & 359 & 357 \\
\hline 2. Securities other than shares & 2,212 & 2,388 & 2,588 & 2,898 & 3,147 & 3,426 & 3,797 & 4,337 & 4,756 & 5,037 & 5,396 & 6,042 & 6,557 \\
\hline 2A. Via domestic financial institutions & 1,688 & 1,908 & 2,056 & 2,337 & 2,523 & 2,756 & 3,085 & 3,681 & 4,036 & 4,256 & 4,581 & 5,081 & 5,328 \\
\hline Credit intermediation ratio $[=1 /(1+2)]$ & $25 \%$ & $25 \%$ & $26 \%$ & $26 \%$ & $26 \%$ & $27 \%$ & $27 \%$ & $25 \%$ & $25 \%$ & $25 \%$ & $24 \%$ & $23 \%$ & $21 \%$ \\
\hline Market intermediation ratio $[=2 \mathrm{~A} /(1+2)]$ & $50 \%$ & $53 \%$ & $52 \%$ & $53 \%$ & $53 \%$ & $54 \%$ & $54 \%$ & $58 \%$ & $58 \%$ & $58 \%$ & $59 \%$ & $61 \%$ & $60 \%$ \\
\hline Total intermediation ratio $[=(1+2 \mathrm{~A}) /(1+2)]$ & $75 \%$ & $78 \%$ & $79 \%$ & $79 \%$ & $80 \%$ & $80 \%$ & $81 \%$ & $83 \%$ & $83 \%$ & $83 \%$ & $84 \%$ & $83 \%$ & $81 \%$ \\
\hline
\end{tabular}

Data: Flow of Funds Account - Bank of Japan. Outstandings on a book value basis. Units: JPY 100,000 millions or \%. 